Portland State University

PDXScholar

1975

\title{
What Indians think an Indian is : a study of personal and educational attitudes
}

\author{
Susan W. Oliver \\ Portland State University \\ Christine L. Peterson \\ Portland State University
}

Follow this and additional works at: https://pdxscholar.library.pdx.edu/open_access_etds

Part of the Race and Ethnicity Commons, Social Welfare Commons, and the Social Work Commons Let us know how access to this document benefits you.

\section{Recommended Citation}

Oliver, Susan W. and Peterson, Christine L., "What Indians think an Indian is : a study of personal and educational attitudes" (1975). Dissertations and Theses. Paper 1791.

https://doi.org/10.15760/etd.1790

This Thesis is brought to you for free and open access. It has been accepted for inclusion in Dissertations and Theses by an authorized administrator of PDXScholar. Please contact us if we can make this document more accessible: pdxscholar@pdx.edu. 
AN ABSTRACT OF THE PRACTIOUM OF Susan W. Oliver and Christine I. Feterson for the Waster of Social Work presented June 25, 2975.

Title: What Indians Think An Indian Is: A Study of Personal and Educational Attitudes.
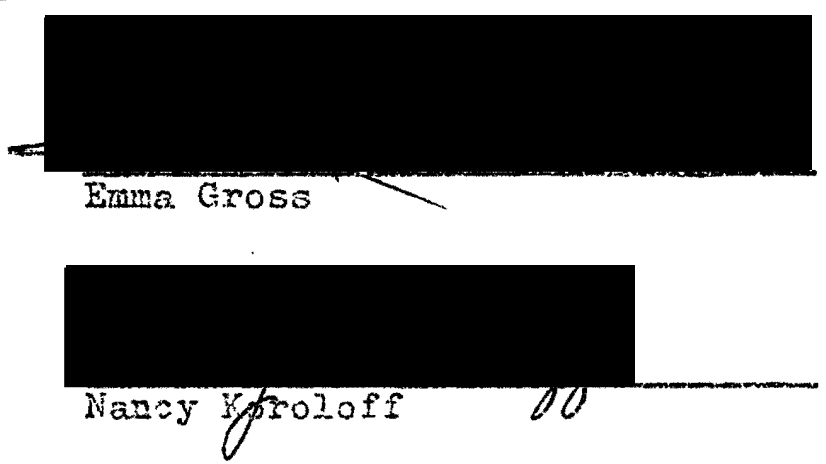

This atudy, was corducted with four Irdian groups: three of Portland and one in thiteriver, Arizona. The puroose of the stucy was to identify attitudes aboul Indian identity and education through the use of a questionnairs on Indian stereotgoes. Each group was unique in its sespcrise. Members of each group all. had a differeat frane of reforence for "who an Indian is." Therefore, a conclusion could rot be drain because of the aifferences in attitudes between all four Indian groups. 
WEAT INDIANS THINR AN INDIAN IS:

A STUDY OF PERSONAI AND EDUCATIONAL ATTITUDES

\author{
by \\ SUSAN W. OLIVER \\ and
}

CHRISTINE L.. PETERSON

A practicum submitted in partial fulfillment

of the requirements for the degree of

MASTER OF SOCIAI WORK

Portland State University.

1975 
TO THE OFFICE OF GRADUATE STUDIES AND RESEARCH

The research advisors approve the practicum of Susan W. Oliver and Christine I. Peterson presented June 13, 1975.

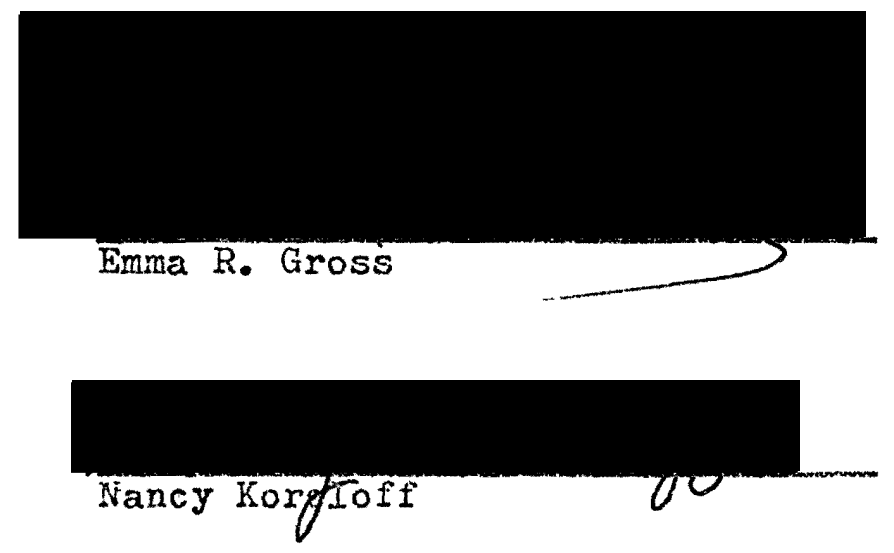




\section{ACKNOWLEDGMLNTS}

The authors would like to thank Emma Gross for her assistance, support, patience, understanding, insight and influence. Our gratitude to Nancy Koroloff and Frank Petersen for their advise and technical assistance. Most of all, we would like to thank the Indian people who participated in the study. 
TABIE OF CONTENTS

PAGE

ACKNOWLEDGMENTS . . . . . . . . . . . . . . . . . . iii

CHAPTER

I INTRODUCTICN . . . . . . . . . . . . . . . I

II METHODOLOGY ................... 9

III Questionnaire. . . ........... . 9

Description of Organizations and Groups. . . . I?

Actual Administration. . . . . . . . . 22

Iimitations ................. 23

III FINDINGS ................ 26

Demographic Data . . . . . . . . . 26

Definition of Being Indian . . . . . . . . 28

Indian Experience of the Urban Indian. . . . 29

Contact With the ion-Indian World. . . . . . 31

Educational Attitudes, Experiences and

Perceptions of Epportunity . . . . . . . 33

Responses to Questions by Educational

Level Completed. ........... . 35

Summary. .................. 35

IV IMPLICATIONS AND CONCLUSIONS. . . . . . . . 37

Definition of Being Indian . . . . . . . 37

Indian Experience of the Urban Indian. . . . . 45

Contact With the ion-Indian iorld....... 47

Educational Experiences, Attitudes and

Perceptions . . . . . . . . . 52

BIBLIOGRARHY . . . . . ............ 65

APPENDIX A

APPENDIX B 


\section{CHAPTER I}

\section{INTRODUCTION}

North American Indians, or Amerirdians, or Indian-Americans, and more recently, Native Americans have beeil the subject of much anthropological theorizing, interrogation, and analytical interpretation by anthropologists and students of anthropology since the $3880^{\prime}$ 's especially in America's Southwestern region. ${ }^{1}$

Earlier than this, various scientists with exploring expeditions and a few military men who had come ostensibly to fight Indians, made discriptive enthnographic coments and sometimes even had expedition artists of photographers malse pictures of natives they encountered.

These people nonetheless have had very little personal involvement with the various Indian populations that they have studied.

The authors of the present study, however, are not anthropologists, but have had personal involvement with Indian people who have, as well, participated in the study. "Pexsonal involvew ment" means the sharing of a common ancestry; an empathy with the first Americans. In short, the authors themselves are Indians. This study is on Indian peoples attitudes and educational backgrounds and how the Indian respondents perceived the question:

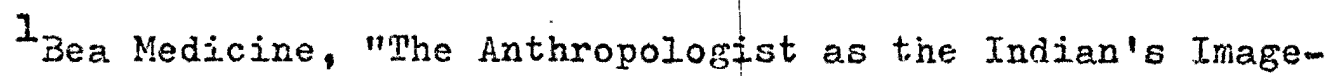
Maker," The Indian Historian, IV, No. 3 Fall (1971), 27.

${ }^{2}$ Bernard I. Fontana, "Savage Anthropologists and Unvanishing Indians of American Soutiwest," The Indian Historian, VI, No. 1 winter $(1973), 6$. 
"Who is an Indian". The authors' personal definition of what being Indian involves is as follows.

The Indian is an individual who is enrolled on the tribal census-roll book. The tribal census-roll book is kept by each tribe for its members. Enrollment for each tribal group varies from tribe to tribe, because each tribe has its own constitutional by-laws which set forth the specific qualifications for enroliment into the tribe. Once an individual has met tribal qualifications and is enrolled as a member of the tribe, then he is entitled to certain tribal rights and benefits. An example of a tribal right could be the right to vote in tribal elections. A tribal benefit couid be an educational fund set aside by the tribe to be used as a scholarship fund for higher education. The definition of an Indian also includes one who has resided on his tribal lands or the reservation ${ }^{3}$ most of all his life and is, further, a member. of an extended family. The authors will use the Dictionary of Anthropology definition of "extended family":

3 Indian reservations were established in order to place some control on the Indians in the early days and also as a place to put the Indians that had been moved away from their native areas when the settlers moved in, in large numbers. Certain rights were given the Indian who lived on the reservations. These revervations were usually not the most choice of lands and the Indian feelings were not al.ways considered during their "renoval". Much has been done to improve the lot of the Indian on the reservam tions but at the same time a movement is also under way to "terminate" these people, which will absorb the Indian and his land. As a race he will soon disappear. (John I. Stoutenburgh, Jr., Dictionary of the Araericon Indian, (New York: Fhilosophical Library, 1960), p. 351.) 
A family consisting of series of close relatives along either the male or female line, usually not along both. A woman, her husband, their children and her married daughters with their husbands, or a man, wife, his childref, his sons and son's wives would each be extended families.

In adition, our Indian knows his tribal language and customs; participates in tribal ceremonies such as tribal harvest fairs and tribal religious ceremonies. 5 Furthermore, he has had some experience with a government boarding school, such as the shonto Boarding School. This school, for example, is an on-reservation school under the jurisdiction of the Bureau of Indian Affairs office, as such schools always are, at Tuba City, Arizona. The school is entirely financed and adminstered by the BIA, and has an annual operating budget of over one million dollars. 6

Shonto is "located in the northwest corner of the Navajo Reservation, the area is characterized by a complex system of hifhlands and mesas, generally referred to as Shonto Plateal, deeply disected by parallel canyons which drain the area. An isolated area until recently, Shonto is now connected by rqads to Flagstaff, Arizona...120 miles to the southwest.

In this study, the above definition will be used throughout as the definition for Indian.

Such a definition does not reflect the point of view of everyone who participated in the study. The authors' themselves

${ }^{4}$ Charles Winick, Dictionary of Anthropology, (New York: Fhilosopistcal Liorary, 1956), p. 203.

Barnard L. Fontana, "Savage Anthropologist and Unvanishing Indians of American Southwest," The Indian Historian, VI, No. 1 Wister $(1973), 32$.

6 Estelie Fuchs and Robert J. Havighurst, To Live on this Earth: American Indian Education, (New York: Añchor Press, 1973), p. 46.

$$
7 \text { Ibid., p. } 40 .
$$


each reflect variations of the given definition. Ms. Peterson, for example, has been raised in an urban environment. She has received all of her education in an integrated public school, and has lived on a reservation for a total of less than five years. Although she has lived most all her life off tribal lands, she does have close personal contacts with relatives still residing on tribal lands, somewhat complicating this particular distinction. She has reinforced her Indian-ness, always a tenuous identity when residing in the city, for long periods of time. She has, for example attended Indian dinners, and various Indian meetings held periodically throughout the city of Portland. Ms. Oliver, on the other hand, was born and rajsed on a reservation where she spent her first twenty-two years. In addition, she has maintained close personal contact with Indian people and relatives residing on tribal lands. Moreover, she attended a public school on the reservation from the fourth grade until she graduated from high school in 2966; and only recently, in order to attend college, has she ventured into an urban enviromment. The authors' definition of what an Indian is, as our personal histories iliustrate, is not typical of all Indian people. The two contrasting descriptions, if anything, illustrate that there are, at least two, and possibly many more, variations on the definition. Other variations of the definition, could include;

Some persons (who) are on the rolls of organized tribes, others (who) are not; some Indians maintain traditional Iife styles and are frequently referred to as "fuIl bloods". Although they may be of mixed ancestry, others represent various degrees of acculturation in relation to the white society; some live in isolated rural regions, others in major industrial centers; some speak a native language as a home 
language or none at all; some tribal members are "progressive" in that they lean toward institutions and political structures removed from traditional kinship and religious systems of political control, others are "conservative" their allegiance remaining with traditional systems of political control; some tribes have reservation lands and close ties to the federal government... others have no federal trust lands and have lost, through termination, claim to special federal services... some are living on reservations which are synonymous with ancestral homelands, others have had histories of forcible removal from traditional place of occupation. In addition to differences in degree of Indian ancestry; the diversity of Indians is further compounded by a wide variety of ethnic differences among the tribes, differences in historical experiences, differences in educational levels, as well as differences between generations. 8

It is this vast discrepancy in the experience of those who are called, or who call themselves "Indian". that the authors" hope to demonstrate by this study.

Orifinally the study was designed to find out if there were differences between two Indian organizations in Portland, Oregon. This desire was motivated by the personal observations of oce of the authors. These same observations were made during the 1973-1974 school year. Because, during this period of time, the author had begun her graduate work in Portland, she became inter. ested in Indian community events that periodically took place on the Portland State campus. She experienced, on one or two separate occasions, for example, Indian street demonstrations organized by members of the Urban Indian Program (UIP), a typical urban center for and therefore operated by Indians. 9 The organ-

8steIIe Fuchs and Robert J. Havighurst, To Iive on this Earth: Anerican Indian Education, (New York: Anchor Press, 1973), p. 45.

9ack 0 . Waddell and 0 . Michael. Watson. The American Indian in Unoan Society, (Boston: Ijttle, Brown and Company, 1971), 1. 197. 
izers were young adults all wearing Indian beads and head bands, and having long or braided hair, including some who were white. On each occasion the author observed that the same group of people almost always appeared to participate in the demonstration. Both times the same speakers or leaders presented the same "Oppressed Indian" speeches. At about this time, she learned that a second Indian organization, different in organization and political ideology, existed in Portland. This organization, the Fortland American Indian Center (PAIC), interestingly, did not support Indian demonstrations. Its members, consisting of older Indian people, the majority of whom were employed and had families, did not support "activist" demonstrations.

In Portland these are the two major Indian organizations. Instead of a cooperative effort between the two centers, there appears to be rivalry. A major factor of the rivalry between the Urban Indian Program and the Portland American Indian Center, has been the matter of funding. The Urban Indian Program had its beginning in 1972, with a four member, salaried staff. Its purpose was to provide contact and referral services to the Indian commity. The Urban Indian Program is governed by the Urban Indian Council. The Urban Indian Council has been composed of representatives from the Irdian community and provides a medium for individual Indians to express their opinions and neeas, as well as to contribute to Councis business. The Portiand American Indian Center began in 1959. Serving the Indian peoplesi reeds, from housing to youth programs, its emphasis was on newly arrived Indian individuals and families. The 
Portland American Indian Center has had representation on the

Urban Indian Council although it has continuad to operate a separate program. 10

Funds provided by the Office of Economic Opportunity were distributed to Region Ten by the Portland Metropolitan Steering Cormittee, where both the Urban Indian Program and the Portland American Indian Center are located for federal administrative purposes. 11

The Indian community split into factions over the battle for federal funds. One faction supported the Urban Indian Frogram; another faction supported the Portland American Indian Center. Each group wanted the funds to be awarded to the Center they supported. The faction supporting the Urban Indian Frograr felt the monies should be awarded to the Urban Indian Council since it represented the Indian community. The second faction felt the monies should be awarded to the Portland American Indian Center because its member were professionals, that is, Bureau of Indian Affairs employees and educated, therefore more able to administer the funds. 12

Eventually, the Office of Economic Opportunity monies were awarded to the Urban Indian Council. The Portland Metropolitan Steering Committee's rational for awarding its funds to the

${ }^{10}$ Iyndon Earl Bohanan, The Urban Indian Program in Portland, Oregon, an unpublished paper, pp. $20-26$.

II Iosd.

22 Pranis Petersen, Enalysis of Portland Urban Indian Program, an unpublished paper, pp. 2.m. 
Council was that the Council represented more Indian organizations, and therefore more members of the Indian community, than did the Portland American Indian Center. What resulted was a permanent split between the two groups, apparently because of the Portland Metropolitan Steering Committee's ruling. Ultimately, the Portland American Indian Center withdrew as a member of the Urban Indian Council. 13

There are various definitions for Indian-ness. Indian-ness is felt and looked at differently by different groups and individm uals of various degrees of Indian ancestry. The split between the two major Indian organizations could be representative of two different beliefs and attitudes held by the menbers, regarding who is an Indian. This study is an attempt to identify what the majority of the respondents feel an Indian is.

13 Frank Petersen, Analysis of Portland Urban Indian Program, an unpublished paper, פ. 3 . 


\section{CHAPTER II}

\section{METHODOLOGY}

\section{Questionnaire}

The questionnaire for the study was constructed by the authors with the intent of designing an instrument which could identify some common experiences Indian people share in order to correlate these experiences with personal and educational attitudes about being Indian.

The questionnaire itself consists of two major sections: a cover sheet requesting demographic data, and a section consisting of twenty-five attitude questions which can be reiated to variables chosen from the demographic data.

The demographic data related to common experiences Indians were believed to share. These variables included tribal. identj.fication; enrollment; location of tribal lands; length of residence on the reservation; contact with current residents of the reservation; the ability to speak the tribal language; types of education (Bureau of Indian Affairs School or Public School); location of school (off tribal lands or within the boundaries of tribal lands); and the level of education completed. Sex, age and marital status were obtained for further correlation. Tribal identification is defined as a feeling of associm ation with a particular tribe. It is possible for an Indian person to be associated with more than one tribe because of 
mixed marriages in his backgrcund. The Indian person whose blood degree is four quarters of one tribal blood is becoming less common. If an Indian person of one tribe marries outside his tribe to an Indian person of another, they must choose for their offspring which tribe to be enrolled in. Therefore, it is possible for a person to be: half Sioux and half Yakima, but be recognized legally as only half Indian on the reservation where he is enrolled.

Enrollment is a complex subject. When an enrolled member a person whose name is on the official list of tribal members of a tribe has a child it is his responsibility as the parent to see that he/she is formally entered into the rolls by completing legal documents. Some tribes have closed their rolls to individuals who were born after a certain date and have a blood degree below a quarter even though a parent is enrolled, for example, the Fort Peck Reservation on December 31, 1960. This decision is made by tribal councils and the requirements for enrollment vary.

Members of terminated tribes are in a different position. With termination, members of these tribes gave up their federal status for any of the federal services offered to Indian people. The children of terminated tribes have no rights as Indians and cannot be enrolled in the same sense that Indian childrea of non-terminated tribes can be. The Klamath and Siletz tribes of Oregon are examples of terminated tribes.

Briefly, terminated meant that the government would end its special relationship with a certain tribe, thus cutting off medical services, educational and other funding, and 
making land taxable. This was tried twice, under protest against the Klamath and Mopominee tribes and in both cases it reduced people who were nearly self-sufficient to the welfare level in a matter of a few years. It

The reservation system in the United States varies great]y.

A formal definition of a reservation is:

A reservation is a tract of land owned by a tribe, the land being hej in trust by the federai government for the use and benefit of the tribe. Land within a reservation can include land covered by exclusive titles, independent Indians communities, and Indian allotments where the title has not been extinquished. There exist approximately 300 separate Indian land units (reservations, plieblos, colonies, rancherias, and communities) under the administration of the Bureau of Indian Affairs, along with scattered allotw ments in the public domain. 15

Basically, a reservation is a land area whose boundaries are set by treaty agreement. The land may or may not have been the traditional lands of the Indian people living there. The reservaw tion system originally implied a unique relationship between the tribe; state and federal government. Legal Negotiations were to be between the tribal government and the federal government as though the tribe was a sovereign nation. Public law 280 has changed this concept in some states:

State jurjsdiction over reservations depends on where the reservation is located. Nost places where Indians live east of the Mississippi have no federal status as reservations, and in these cases the states maintain law and order. Wost of the Indians involved dislike this system, because states have an even worse refubation than the federal. Government for protection Indiar rights. Indian prople have no choice in the ratter. Iieither did the tribcis in the five westem states that assumed jurisdicm tion over the reservations during the ere of termination.

14 Robert Burnette ard Jonn Koster, The Road to Wounded inee (New Yoris: Bantam Books, 1974): p. 16-17.

25,Hucoro E, Washourn, Red Nan's Land- Mite Man's Law

(New Pori: Charies Scribner's Sons, 2971) p. 206. 
With a stroke of the pen, on 15 August 1954, Public Law 280 gave the states of Washington, Oregon, Nebraska, Minnesota, and Wisconsin jurisdiction over the reservation within their border.16

The questions about length of time spent on the reservation and contacts with reservation residents are important, as some social scientists believe the reservation is the only transmitter of Indian tradition. 17 Wher an Indian person leaves his reservation, he leaves behino the traditional religious ceremonies, celebrations and feasts that are unique to his tribe and reservation; as well as the raw materials that are used in his crafts. Perhaps, most significantly, he leaves behind a group of people to whom these ceremonies and crafts have special meaning. This places the Urban Indian, for example, in a questionable positior as far as carrying on his culture and traditions. All the respondents to the questionnaire have sought out Indian groups. Can these groups take the place of the tribal communty in supporting tradition? Is this why Urban Indians join Indian groups? These questions will not be answered within the scope of this study, but we will indicate something of the level of importance Urban Indians place on the continuation and knowledge of their traditional ceremonies and crafts as an example of the effort to retain or rediscover their "Indian identity."

The ability to speak a tribal language seems to be becoming

16 Robert Burnette and John Koster, The Road to Wounded Knee (ivew Iork: Tantain Books, I974), p. 313.

17 Alexander Lesser, "Education and the Future of Tribalism in the United States: Nhe Case of the American Indian," Social Service Reviey, XYV (Juna 1961), p. 133. 
rarer in the general population of Indian people. Anthropologists have historically defined language as an aspect of culture. A study published by the Northwest Regional Laboratories refers to the ability to speak and the extent to which an Indian language is spoken as " 'cbvious' marks of "Indian-ness". "18

The Bureau of Indian Affairs has played an important role in the education of Indian people in the past. Many Indian children have been removed from their families at early ages to be educated in BIA Boarding Schools. Currently, the trend is to develop and support (with federal funds) public schools in Indian communities, where feasible. In some areas, the Indian population has been educated in the public schools on tribal lands; these public? schools are often integrated. I'his is most common on reservations where there is a large non-Indian population such as the Fort Peck Reservation in Montana.

More and more children are attending the public schools or - where these are not available - special Indian day schools and living at home. Boarding schools, where required, are coming closer, although too many teenagers are still being sent to distant places to use plants no longer needed for local tribes. The bureau has no contact with the children in the cities or in rural areas away from reservations and trust lands. Even in localities where there is Indian-owned land, 152,000 children attend public schools; and these schools receive subsides to balance the loss in taxes, just as do schools near defense installations or other "federal impact areas."

18 Alphonse J. Selinger, The American Indian Graduate: After High School, What? (Portiand: Northwest Regional Educational Laboratory; 1968), p. 37.

I9 Angie Debo, A History of the Indians of the United States (Norman:: Unjuersity of OkIahoma Press, 1970), p. 348. 
Children of terminated tribes would also be integrated into public school systems.

Questions about the level of education were included primarily for correlation with the attitude questions about education. How do individuals who have completed different levels of education view their educational experiences and opportunities? Does a positive view of the opportunites available to Indian students and a positive view of the Indian school experience correlate positively with the level of education achieved? And, at the other extreme, do the people who were dropouts view the opportunities available and the school experience negatively?

The attitude questions in general were chosen by the autbors of the questionnaire to elicit responses which could be used to make statements concerning: the definition of being Indian; Indian experiences of the Urban Indian; contact with the non-Indian world; educational; experiences; and attitudes toward education and perception of educational opportunities.

Questions $1,2,3,4,5,14,15$, and 17 were developed from the authors' personal definition of Indian:

1. To be an Indian is to be able to speak both his tribaj. language and "English".

2. To be an Indian is to know his native customs and traditions.

3. An Indian is an individual with a unique cultural background.

4. To be an Indian is having parents and relatives who live on a reservation.

5. To be an Inajan is to know one's native crafts, for example, beading and Heaving. 
14. To be an Indian is to become a professional (Social Worker, Aaministrator, etc.) yet keep all his "Indianness".

15. To be an Incian is not "selling out" to the white man's world, and becoming an "Apple Indian". "Apple": An Indian who copies whites or emulates middle-class white values and life-style: "red on the outside, white or the inside.") 20

The intent was to determine whether or not the respondents believe that the possession of these abilities, experiences and attitudes is a part of Indian identity. It does not ask if they possess these abilities, experiences and attitudes but whether or not such are part of their definition of being Indian.

Questions 6,7 , and 8 were included because the authors' personal experience in Portland had indicated that participation in rodeos or participation in city Pow Wows and support of the American Indian Movement were positively viewed by many of their peers. These ideas were new to them and did not fit their personal definition or experience as Indian:

6. Most Indians like to participate in rodeos.

7. To be an Indian is to participate in Pow Wows held in the city.

8. To be an Indian is to support the American Indian Movement (AIM) and its leaders.

Questions $9,10,11,12,13$, and 16 are concerned with Indian peoples contacts with the non-Indian world. They are phrased to elicit responses about the reality of interaction between Irdians and non-Indians; as well as interaction between Indians and Indians in the urbar setting. question 21 differs

20 Robert Burnette and John Koster, The Road to Wounded Xned (New York: Bantam Books, 2974), p. 16-27. 
slightly in that it asks for a response to the phrase "Most Indians feel". It asks for a response- that indicates the way things should be rather than the way they are:

9. Some Indians try to force others (both Indians and nonIndians) to see their point of view.

10. Nost Indians do not have a college education or a college degree.

12. Most Indians feel there should be more Indians working in government (BIA/IHS) supervisory and/or administram tive positions, than in clerical positions.

12. Most Indians like to be with people who share their ideas and beliefs in group discussions and meetings.

13. Most Indians have a lot of white friends and associates.

16. Most Indians learn the way of the "Whiteman" in a government boarding school.

Questions 18 through 25 deal directly with educational experiences; attitudes toward education, and perception of educational opportunities:

18. To be an Indian is to suffer discrimination in the public schools.

19. Most Indians can learn more and be more comfortable when they attend school with other Indian students.

20. A12 Indian children should have the chance to attend a public, integrated school.

21. In the past Indians received a "second rate" education.

22. Al2 students, Indians and non-Indians, should be required to take classes in Indian History and Culture.

23. It is difficult for Indian children to adapt to schools in Portland/Phoenix.

24. The high Indian dropout rate is caused by the school situation rather than the lack of ability on the part of the Indian student.

25. Today's Indian has the same educational opportunites as a non-Indian. 
The questions were chosen on the basis of feeling and intuition. The authors' sensed that a difference in some of the attitudes about Indian identity were present in the Portiand Indian community. These attitudes were different from those they had experienced on their respective reservations. This difference was in part attributed to the urban situation; in part, perhaps, to the effects of the new Indian activism. The questions were arbitrarily developed in order to test the authors' perceptions and, if possible, to determine how other Indians themselves might define Indian-ness. In this way, perhaps, some common elements of a definition might be identified.

Description of Organizations and Groups

The respondents were classified as being members of one of four groups: the Urban Indian Program (UPI); The National. Council of off Reservation Indians (NCORI); The Bureau of Indian Affairs (BIA); and the Indian Health Services (IHS). The distinctions were made according to the respondents physical location when they completed the questionnaire and are not necessarily congruent with place of employment.

The respondents were found by attending meetings and gotherings of Indian people in the Portland area and by visiting the Indian Health Service group in Whiteriver, Arizona. The choice of this method of locating respondents was adopted as there were no available sources for names of Indian people in the Portland Area. 
The Urban Indian Program

The Urban Indian Program is a social service Program -primarily contact and referral -- directed toward meeting the individual and family needs of Indians for direct services. Some of the services are as follows; Cultural Identity; Social Services Referral and Contact; Alcohol Referral; Educational. Counseling; Employment Services; Emergency Housing; Legal Assistance; and Health Services. 21

The questionnaire was administered to three groups associated with the Urban Indian Program. The Urban Indian Program provides physical facilities for two of the groups to meet and some of the members of each groups are employed by the Urban Indian Program. These groups were The Right to Read Tutoring Program, Win-ya, and the Native American Youth Association. The Right to Read Tutoring Program, noused in the Urban Indian Program offices two nights per week, involves Indian people of all ages, from high school students to middle-aged. These were present on the evenings the questionnaire was admiristered. The purpose of the Right to Read Program is to provide preparation for the General Equivalency Exam (G. E. D.) and tutoring for high school students who are presently enrolied in high school. The program has no entrance requirements and there is no required attendance. Participants vary from week to week.

${ }^{2 I}$ Iyndor Earl Bohanan, The Urban Indian Program in Portland, Oregon, an unpublished paper, 1974, p. 8-10. 
Each person in this group was approached individually and asked to complete the questionnaire. They were told it was pari of the requirement for the authors' graduation from Portland State University. The respondents were generally co-operative; there were no refusals and only a few people asked for more information concerning the use of the questionnaire.

Win-ya is a group of Indian women who meet bi-monthly in the office of the Urban Indian Program. Win-va members are involved in volunteer work in the Indian community and have classes in beading and other cultural crafts for their members. Recently, they have been involved in raising support, financial and psychological, bor Betty Heath, an Indian woman who has been convicted of murdering her husband. These social and civic aspects of the meetings seems to be an integral part of the purpose for the group. The women's ages range from the midtwenties to mid-fifties.

Win-ya was approached at a meeting and unanimcusly agreed to participate in the study. They were also told it was part of the requirement for the authors' graduation from Portland State University.

The Native American Youth Association consists, in theory, of young. people from junior high school to high school age. The meetings actually include total families from infants to parents and grandparents. The meetings are held on Saturday: in a Portland church basement. Activities are planned for the youth by the volunteer staff and a potluck dinner for the families is held late in the afternoon. The Director of the Right to Read 
Tutoring Program is also involved in this group and there is an overlap in membership between the participants in the Tutoring Program and the Native American Youth Program. As many of the members of both groups were known personally to the authors, we relied on recognition to prevent individuals from filzing out two questionnaires.

The questionnaires were given at two Native American Youth Association Potluck Dinners. Each individual or group at a table was approached and asked if they would participate. They were also told it was part of the requirements for the authors.' graduation from Portland State University. In general, most of the adults were willing to participate. One woman refused to complete the questionnaire. The reason she gave was that she had been a student in the Indian Education Program attending Portland Community College, and she felt that the students at Portland State University in the Indian Education Project ignored the students at the Community Coljege. She was therefore resentful and would not co-operate.

\section{National Council of off Reservation Indians}

The National Council of off Reservation Indians (NCORI), local chapter, is a relatively new organization. The purpose of the orgarization as stated in their Constitution is: "To Create, through the strength of unity a national organization to fill the needs of off reservation Indians." The philosophical. preamole includes this statement concerning education:

We believe that education is the foundation for the cultural gronth and development of our people and that 
we are obligated to promote, protect and assure the right of our people to an education that is in accordance with the bighest educational principles and standards, that we must deplore any infringement of this right wherever it may occur and regardiess of whom it may affect.

The National. Council for off Reservation Indians was involved in writing this constitution and by-laws at the meeting we attended. It was one of the first large meetings and it was held at Mount Hood Community College. Permission to attend was obtained frou Gil Minthorn, Vice President of NCORI, by phone. All the members willingly tcok the questionnaire before the meeting started. of all the groups involved, they exhibited the most interest in the results. Several individuals requested copjes of the results and some were under the impression that the results would be available at that meeting.

\section{Bureau of Indian Affairs}

The Bureau of Indian Affairs employs many Indian people in Portland. Upon a formal written request, the Area Director allowed the questionnaire to be administered during business hours. A room was assigned; hours set, and a memo circulated to the employees to anxounce the time and place. The employees were al. Lowed to leave their desks to participate; however, the level of participation was low. (sixteen participants.)

The low level of participation may have been caused by a lack of interest in the Bureau of Indian Affairs employees in Indian Activities other than their own. By our observation Bureau employees tend to be more stabie in theix residence and occupation and this may reflect a tendancy to pursue personal 
advancement and achievement. Such self-interest may welJ. take priority over interest and involvement in the needs of the Indian community as a whole. The possibility also exists that the employees did not feel they could take time from their duties to participate. Some of the respondents seemed rushed and two requested to take the questionnaire to their desks so they would be close to the phone while they were completing it.

\section{Indian Health Service, Whiteriver, Arizona}

The Department Heads of the Indian Health Service Hospjtal on the White Mountain Apache Reservation (Ms. Oliver's home) consented to participate in the study after approval was received from the Hospital Administrator.

Ms. Oliver visited the hospital and diacussed the questionnaire with the interested department heads. The departments involved were: Nursing Supervision; Social Services; Admission and Records; X-Ray Technology; and the administrative support staff.

The respondents were very co-operative. Ms. Oliver felt their co-operation stemmed from the fact that they felt pride that an Indian person from their reservation was receiving advanced education and they wished to do whatever would help.

\section{Actual Administration}

The methods used in the administration of the questionnaire were adapted to the settings in which the respondents were found as stated in the group descriptions. The general instructions were kept as uniform as possible. They were: this questionnajre 
is part of the requirement for my degree from Portland State University. The information is confidential. The first page asks for some background information; and the second and third pages ask some questions that require your attitudes or feelings about certain subjects or ideas. There are no right or wrong answers - just opinions. Check the first column if you agree; the last column if you disagree, and the middle column if you dc not know.

Names were not requested, although some respondents indicated $a$ willingness to be identified by asking where they should put their name. The names and addresses of respondents wishing copies of the results were taken.

There was no time limit imposed in any of the situations. The setting in most cases was not conducive to endorcing a time limit. The reading level of all respondents, for example, was not known and it seemed that some needed a great deal of time to complete the questionnaire possibly because of a limited reading ability. Most of the respondents seemed to take their time; although among the Bureau of Indian Affairs employees there seemed to be hastiness. This could have been because the BIA employees left thejr desks to come to a specific area to complete the questionnaire, while the other respondents had the questionnaire administered to them where they were and at their convenjence.

Iimitations

The major limitation of the study was the unavailability 
of sources for names of Indian people in the Portland area. The numbers of the Portland Indian population, for example, ranges from three thousand to seven thousand depending on the survey cited. Identification of numbers is complicated by the fact that Indian people tend to move -- in and out of the city and from place to place in the city - frequently. 22

The Urban Indian Program and the Portland American Indian Center were approached as sources for names of Indian people who were associated with their respective programs. The Urban Indian Program stated they did not have a list of clients. When approached for permission to give the questionnaire to clients actually present in the Urban Indian Program offices, permission was refused. This was qualified by the statement that their clients had so many forms to fill out to receive assistance that they did not wish another form inflicted upon them.

The Portland American Indian Center refused to give their membership list because they had given it out on previous occasions and received complaints from the members. They did give permission for attendance at their meetings to ask the attending nembers if they wished to participate. However, the meeting which was held during the time of administering the questionnaire was cancelled. Therefore, Portland American Indian Center nembers were not involved in the sampling as members of the Portiand American Indian Center. Some were included because they were part of the Bureau of Indian Affairs group and the

22 Lyndon Earl Bohanan, The Urban Indian Programs in Portiand. Oreson, an unpublished paper, 1974, p. 1 . 
National Council of off Reservation Indians group.

The unavailability of sources of lists of Indian people made the use of a random sample impossible. This greatly limited the type of statements which can be made in the analysis of the questionnaires. The statements about the respondents can only be descriptive of the individuals who were respondents. A random sampling would have given the results a higher level of validity in making statements about attitudes, experiences and perceptions of Urban Indians in the Portland area.

This illustrates a major problem in attempting accurate research with Urban Indian groups. The lack of formal contact with any organization in the urban area and the transientness of Urban Indians makes accurate research almost impossible. 
CHAPTER III

FINDINGS

This chapter presents the demographic data and statistical analysis of the findings of this study. The question responses of the 76 respondents were averaged to determine a mean score for each question. The means were determined for a total population and for each of the four groups; the Urban Indian Program, the Bureau of Indian Affairs, the National Council of off Reservation Indians and the Indian Health Services.

The responses were assigned number values; 5 for agreement, 3 for indifference or neutrality; and 1 for disagreement. The set of means; total population, and the four group means for each question are presented.

The mean is said to indicate agreement if it falls between 4.0 and 5.0 ; neutrality or indifference if it falls between 2.00 and 3.99; and disagreement if it falls between 0.00 and 1.99 .

\section{Demographic Data}

The population of this study consisted of 76 respondents. There were 55 female respondents and 21 male. The average age was 35.57 years with a range of 16 years to 65 years. The majority of the respondents vere married, 44; 22 were single, and 10 indicated they were in the catagory of "other".

The respondents represented 25 tribes with tribal lands in 
12 states. The majority of the respondents indicated they were in contact with friends and relatives on their reservation. 42 indicated they had Iived on the reservation and, of these, the majority had lived on a reservation over 15 years.

The ability to speak more than a few words of their tribal. language was claimed by 29 respondents.

The majority of the respondents received their education in public school systems, 56 respondents; only 19 respondents were educated in Bureau of Indian Affairs Schools. The majority of the schools attended were on tribal lands.

25 of the respondents did not complete J2th grade, 13 completed 12th grade and 29 have completed or attended some past high school educational or training program.

A more detailed presentation of data is given in Appendix $B$. 
Questian Means

TABEE I

DEFINITION OF BEING INDIAN

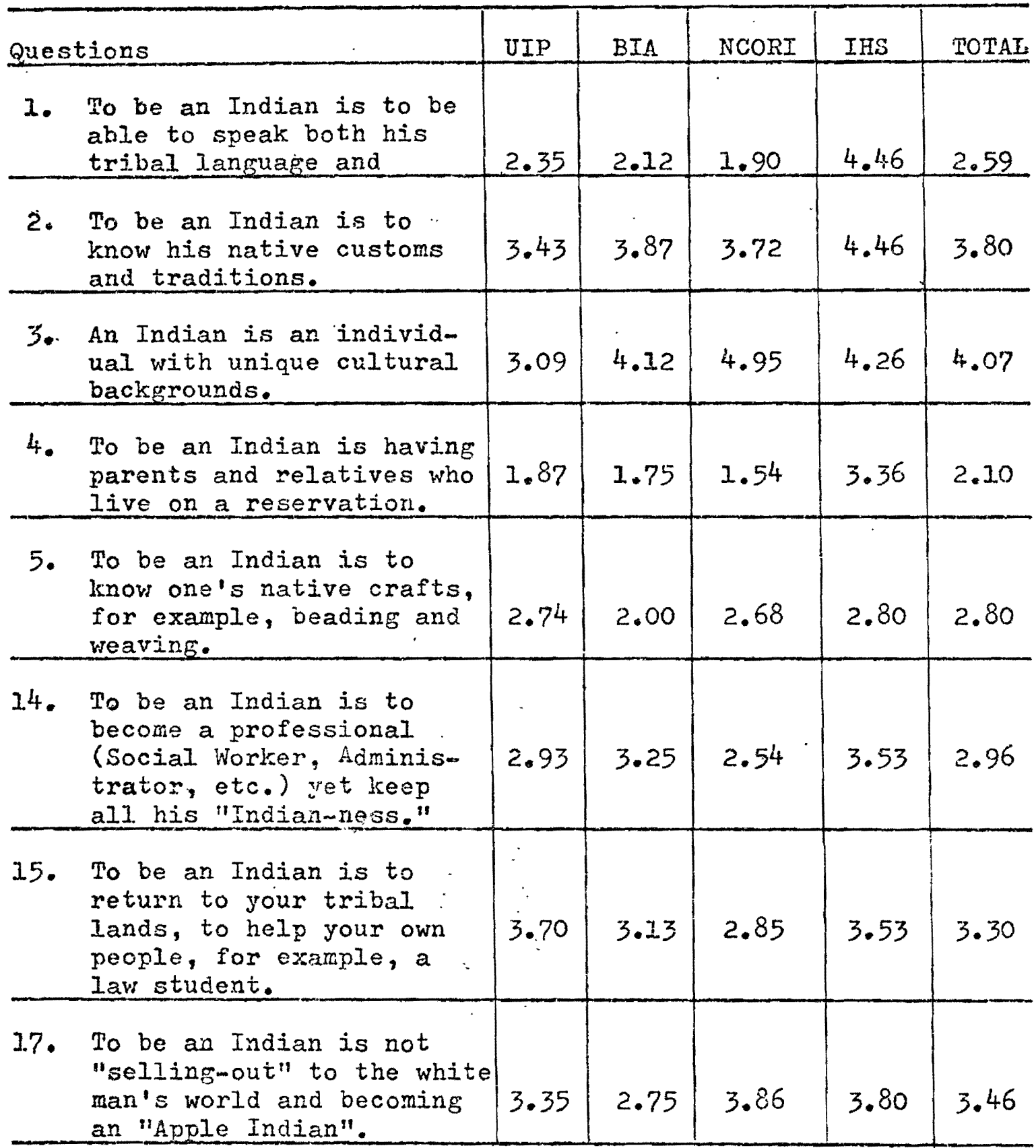

The population means indicate neutrality or indifference on questions $1,2,4,5,14,15$, and 17 . The population mean indi- 
cates agreement on question 3.

The Urban Indian Program (UIP) group mean indicates dism agreement on question 4 ; the means on all other questions for this group fall within the range of neutrality or indifference. The Bureau of Indian Affairs (BIA) group mean indicates agreement on question 3; disagreement on question 4, and neutrality or indifference on all other questions.

The National Council of off Reservation Indians (NCORI) group means indicate disagreement on questions 1 and 4. They indicate strong agreement on question 3 . The means indicate neutrality on all other questions for this group.

The Irdian Health Services (IHS) group means indicate agreement on questions 1, 2, and 3. Their means indicate neutrality or indifference on questions $4,5,14,15$, and 17.

TABLE II

INDIAN EXPERIENCE OF URBAN INDIAN

\begin{tabular}{|c|c|c|c|c|c|}
\hline Questions & UIP & BIA & NCORI & IHS & TOTAL \\
\hline $\begin{array}{l}\text { 6. Most Indians Iike to } \\
\text { participate in rodeos. }\end{array}$ & 2.83 & 3.13 & 2.68 & 3.66 & 3.10 \\
\hline $\begin{array}{l}\text { 7. To be an Indian is par- } \\
\text { ticipate in Pow Wows } \\
\text { held ir the city. }\end{array}$ & 3.08 & 2.88 & $2.8 \mathrm{~J}$. & 2.78 & 2.93 \\
\hline $\begin{array}{l}\text { 8. To be an Indian is to } \\
\text { support the American } \\
\text { Indian Movement (AIM) } \\
\text { and its Ieaders. }\end{array}$ & 3.82 & 1.68 & 2.99 & 2.33 & 2.86 \\
\hline
\end{tabular}

The population means indicate indifference or neutrality

to 2.11 questions. 
The Urban Indian Frogram (UIP) group means fall within the range of neutrality or indifference on all questions. However, on the question concerning the American Indian Movement, there is a slight tendency towards agreement.

The Bureau of Indian Affairs (BIA) group mean indicates neutrality or indifference on questions 6 and 7 ; there is disagreement with question 8 concerning the support of the American Indian Movement.

The National Council of off Reservation Indians (NCORI) group mean indicates neutrality or indifference on all questions. The Indian Health Service (IHS) group mean indicates neutrality or indifference on all questions. There does seem to be a slight tendency towards agreement with the question concerning participation in rodeos and a slight tendency toward disagreement with the question concerning the support of the American Indian Movement. 
TABIE III

CONTECT WITH THE NON-INDIAN WORUD

\begin{tabular}{|c|c|c|c|c|c|}
\hline Questions & UIP & BIA & NCORI & IHS & TOTAL \\
\hline $\begin{array}{l}\text { 9. Some Indians try to force } \\
\text { others (both Indians and } \\
\text { non-Indians) to see their } \\
\text { point of view. }\end{array}$ & 3.17 & 3.88 & 2.86 & 3.26 & $3.2^{4}$ \\
\hline $\begin{array}{l}\text { 10. Most Indians do not have } \\
\text { a college education or } \\
\text { degree. }\end{array}$ & 3.26 & 4.25 & 4.90 & 4.20 & 4.09 \\
\hline $\begin{array}{l}\text { 11. Most Indians feel there } \\
\text { should be more Indians } \\
\text { working in government } \\
\text { (BIA/IHS) supervisory } \\
\text { and/or administrative } \\
\text { positions. }\end{array}$ & 3.82 & 5.00 & 4.00 & 4.13 & 4.09 \\
\hline $\begin{array}{l}\text { 12. Most Indians like to be } \\
\text { with people who share } \\
\text { their ideas and beliefs } \\
\text { in group discussions and } \\
\text { meetinss. }\end{array}$ & 4.00 & 4.38 & 3.72 & 4.46 & 4.08 \\
\hline $\begin{array}{l}\text { 13. Most Indians have a lot } \\
\text { of white friends and } \\
\text { associates. }\end{array}$ & 3.16 & 3.44 & 3.50 & 3.13 & 3.41 \\
\hline $\begin{array}{l}\text { 16. Most Indians learn the } \\
\text { way of the "initeman" } \\
\text { in a government board- } \\
\text { ing school. }\end{array}$ & 3.17 & 2.13 & 2.13 & 3.40 & 2.72 \\
\hline
\end{tabular}

The population means indicate agreement on question I0, II, 12 and neutrality on questions 9,13 , and 16 .

The Urban Indian Program (UIP) group means indicate agreement on question 12 and neutrality on questions $9,10,11,13$, and 16.

The Bureau of Indian Affairs (BIA) group means indicateE 
agreement on questions 10,11 , and 12. The agreement on question 22 is unanimous. Neutrality or indifference is indicated by the means on questions 9,13 , and 16 .

The National Council of off Reservation Indians (NCORI)

group mean indicates strong agreement with question 10. There is also agreement indicated on question 11. The group means indicated indifference or neutrality on questions $9,12,13$, and 26.

The Indian Health Service (IHS) group means indicate agreement on questions 10,11 , and 12. Neutrality or indifference is indicated on questions 9,13 , and 16. 
TABLE IV

EDUCATIONAJ ATTITUDES, EXPERIENCES AND PERCEPTION OF OPPORTUNITY

\begin{tabular}{|c|c|c|c|c|c|c|}
\hline \multicolumn{2}{|c|}{ Questions } & \multirow{2}{*}{$\begin{array}{l}\text { UIP } \\
2.70\end{array}$} & \multirow{2}{*}{$\begin{array}{l}\text { BIA } \\
2.94\end{array}$} & \multirow{2}{*}{$\begin{array}{l}\text { NCORI } \\
3.22\end{array}$} & \multirow{2}{*}{$\begin{array}{l}\text { IHS } \\
2.86\end{array}$} & \multirow{2}{*}{$\begin{array}{l}\text { TOTAL } \\
2.92\end{array}$} \\
\hline 18. & $\begin{array}{l}\text { To be an Indian is to } \\
\text { suffer discrimination } \\
\text { in the public schools. }\end{array}$ & & & & & \\
\hline 19. & $\begin{array}{l}\text { Most Indians can learn } \\
\text { more and be more com- } \\
\text { fortable when they } \\
\text { attend school with other } \\
\text { Indian Students. }\end{array}$ & 3.87 & 2.94 & 3.59 & 4.00 & 3.63 \\
\hline 20. & $\begin{array}{l}\text { All Indian children } \\
\text { should have the chance } \\
\text { to attend a public, } \\
\text { integrated school. }\end{array}$ & 3.78 & 4.50 & 3.72 & 4.00 & 4.00 \\
\hline 2I. & $\begin{array}{l}\text { In the past Indians } \\
\text { received a "2nd rate" } \\
\text { education. }\end{array}$ & 4.43 & 4.13 & 4.40 & 4.00 & 4.27 \\
\hline 22 & $\begin{array}{l}\text { All students, Indian and } \\
\text { non-Indian should be } \\
\text { required to take classes } \\
\text { in Indian History and } \\
\text { Culture. }\end{array}$ & 4.30 & 4.00 & 3.72 & 4.20 & 4.06 \\
\hline 23. & $\begin{array}{l}\text { It is difficult for } \\
\text { Indian children to adapt } \\
\text { to school in Fortland/ } \\
\text { Phoenix. }\end{array}$ & 3.57 & 3.00 & 3.31 & 3.00 & 3.27 \\
\hline 24 & $\begin{array}{l}\text { The hish Indian dropout } \\
\text { rate is caused by the } \\
\text { school situation rather } \\
\text { than the lack of ability } \\
\text { on the part of the Indian } \\
\text { student. }\end{array}$ & 4.00 & 3.25 & 4.31 & 2.93 & 3.72 \\
\hline 25. & $\begin{array}{l}\text { Today's Indian has the } \\
\text { same educationdl oppor- } \\
\text { tunities as a non-Indian. }\end{array}$ & 3.43 & 4.38 & 2.72 & 3.66 & 3.46 \\
\hline
\end{tabular}

The population neans indicate neutrality or indifference on 
questions $18,19,21,22,23$, and 25. However, they did not strongly agree with the statement that all Indian children should have the chance to attend a public, integrated school, or disagree with the statement that the high dropout rate of Indian students is caused by the school situation rather than lack of ability of the Indian student.

The Bureau of Indian Affairs (BIA) agrees with the population means on ali questions with the exception of question 25. The (BIA) group indicates agreement with the statement that today's Indian has the same educational opportunities as a non-Indian. The National Council of off Reservation Indians (NCORI) disagrees. with the population means on questions 20,22 , and 24 . NCORI's mean for the questions concerning Indian children's chance to attend a public, integrated school and the requirement of all students to taire Indian History and Culture classes is within the range of neutrality or indifference. Their mean for the question concerning the educational opportunities for today's Irdian is also neutral. They agree with the statement that the high Indian dropout rate is caused by the school situation rather than lack of ability on the part of the Indian student. The Indian Heaj.th Service (IHS) group mean dîffers from tine population mean on only one statement. The IHs group agrees that most Indians can be more comfortable and learn more when they attend school with other Indian students. 
TABLE V .

RESPONSES TO QUESTIONS I8, 21,24 and 25

BY EDUCATIONAL LEVEI COMPLETED

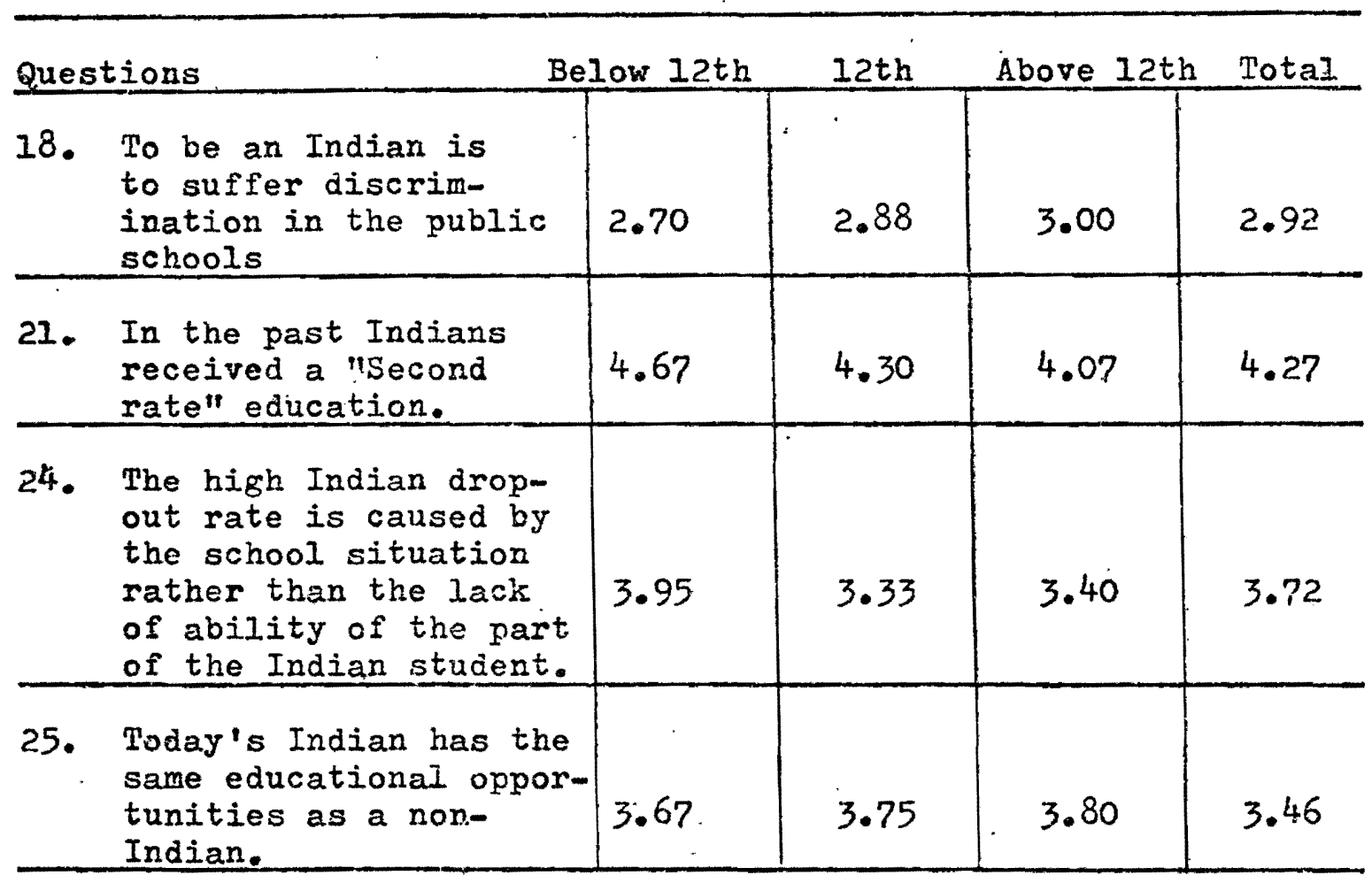

There appears to be little difference in the mean scores of the respondents, when divided into groups according to level of education completed, and compared to the total group means for these questions. The level of education completed group means fall within the ranges of neutrality or indifference on questions 18, 24, and 25. The means agree on question 21. The total group means fall within these ranges also.

\section{Summary}

The population means of 18 questions; $1,2,4,5,6,7,8$, 
$9,13,14,15,16,17,18,19,23,24$, and 25; fall within the assigned range of neutrality or indifference. Seven population means fall within the range of agreement; questions $3,10,11,12$, 20, 21, and 22. However, only on 11 questions; $5,6,7,9,13,14$, 15, 16,18 , and 23 ; do the four small group means agree unamiousiy with the population by falling within the boundaries of the same range, (ie. agreement, neutrality, or indifference.) The implications of this will be dealt with in Chapter IV. 


\section{CHAPTER IV}

\section{IMPIICATIONS AND CONCLUSIONS}

\section{Definiton of Being Indian}

The authors' definition of Indian is reflected in questions 1 through 5, 14, 15, and 17 of the questionnaire. The first five questions reflect the authors' personal feelings of who is "an Indian". Thus, these questions deal with native language, cultural traditions, extended family ties, Indian arts and crafts, and whether or not the respondent viewed his Indian Heritage as unique.

Questions 14,15 , and 17 ask if it is possible for an Indiar to keep his cultural iaentity and still be able to function effectively in non-Indian society. An answer could be, as Richard St. Germaine stated in the book entitled, The Way:
"After he (the young Indian) educates himself in a white world, if he comes back, this is great. I do not dislike the Indian ways ... I only mean that an Indian should first educate himself and socialize with the white world, setting aside his old customs while doing so...then decide which path he shall take." 23

It should be pointed out, that some tribes make it difficult for Indian professionals to return to their own reservations. For example, tribal politics, rivalry, and the pressure of factions

${ }^{23}$ Richard St. Germaine, "Today Young Indians Must Relinquish Their Customs," The Way, ed. Shirley Hill Witt and Stan Steiner (New Tork: Random House, 1972), pp. 93-94. 
among tribal members, could discourage an Indian professional from returning if for no other reason than his world view is now more Iiberal than that of his tradition or status quo bound tribesmen. of the eight questions presented on defining "Indian", the population means indicated agreement on question 3 , ie., an Indian has a unique cultural background. Of the four respondent groups, only one, UIP, indicated neutrality or indifference. Further, the IHS respondents means indicated agreement on questions dealing with language ability, knowledge of rative customs and traditions, as well as with uniqueness of the Indian Cultural background (question 3).

One of the authors' is orginially from the southwest area of the United States. There she had frequent contact with Indian people who spoke both their native language and English. On many reservations in the southwest, English is often a second language. In conversations with an English-speaking person (usually a nonIndian) the Indian person must take in what has been said and translate into his own language before he can respond. ${ }^{24}$ The ability to speak one's native language could be considered a decisive part of one's Indian-ness, 25 since language is so essential an element of personality and culture.

Another part of Indian-ness is reflected in having knowledge about one's native customs and traditions. The IHS respondents 24 Mary Nelson, "problems Indian Students Face" The Indian Historian, V, No. 2 (Summer), 1972, 24.

${ }^{25}$ Northwest Regional Laboratory, The American Indian Graduate: After Hich School, What? November, $1968,0.37$. 
indicateri agreement, due perhaps to the fact that these respondents live and work on a reservation most of their lives (25 years or better). Of the other three groups (UIP, BIA, and NCORI) aproximately one-half of the respondents have lived on a reservation for any period of time (between 1 to 20 years). Indians who live and work on tribal lands may have a better awareness of their Indian-ness. Dr. William Demmert, member of Tlingit tribe of Alaska captures the difference:

His crid years from 8 to 34 were spent the way Tlingits had spent them for generations: Fishing with purse seines in the summer to earn the year's livelihood, spending the other nine months of the year to developing and nurturing a complex society based on such beliefs as reincarnation, dreams, visions and obligations to one's own moiety (clan). Iiving on a reservation with parents and relatives reinforces the development of Indian-ness, especially important if the reservation is ever left behind. Being part of an extended family provides ties both on and off tribal. Iands, thereby delaying the erosion of Indian-ness which occurs after contact with the nonIndian world. Significantly, there were three groups of responaents (UIF, BIA and NCORI) who aII indicated disagreement with the statement: "to be an Indian is having parents and rejatives, who Iive on a reservation". OnIy IHS respondents indicatad agreement with the question. Again, this maybe because most of the respondents in the other groups had no relatives, or, were aware of none, on reservations. Wishing to claim their Indian-ness, however, they could not very well agree with a definition which would $26_{\text {Pragie Wilson, "From Phoenix Convention Center," Axizona }}$ Iiginays, LI, May 1975, p. 15. 
exclude them:

Knowledge of Indian arts and crafts, is not seen as part of a definition of Indian by any of the four groups of respondents. Such knowledge, however, was part of Indian-ness. Iong before the white man come to this continent. Contemporary Indians may experience Indian arts and crafts as a negative stereotype that needs to be forever relegated to museums. This part of being Indian, however, cannot be ignored. In some. Pueblo tribes, for example, all of the women made pots and the men wove in order to provide needed household necessities. 27 The special art skills such as beading and pottery, usually more common among the the women, were passed down to younger women generally through their mothers, who also took instruction from other women, usually relatives. In one instance what resulted among the Cheyenne, and some other Plains tribes, were women's craft guilds. These guilds invited only the most skilled bead workers to meet with them. ${ }^{28}$ some of the tribes still have very famous and well known women, such as Maria Martinez of San I.defonso Pueblo who is known widely for the fine pottery she and her relatives produce. 29 Now that these items of "necessity", however, can be bought cheaply, no one

27 Puth Undernill, Ph.D., Pueblo Craits, (Iawrence, Kansas: Haskell Institute Print Shop), March 1948, p. 135.

28 Andrew Hunter Whiteford, "Enriching Daily Life: The Artist and Artisan," An Exhibition Organized By: Walker Art Center Indian Art issociation, The Minneapolis Institute of Arts, American Indian Art: Form and Tradition, (New York: E. P. Dutton and Co., Inc.), 1972, p. II.

29 Ibid. p. 12 . 
would spend time producing them except for use at a ceremonial, such as a weding. 30 Therefore, the quality of some of the Indian arts and crafts seen today can be determined, usually, by the amount of money paid for the item: "Sales will decide the results, for only an unusual woman can take time for good pots when the average buyer wants. twenty-five-cent ash trays." 31 With this in mind, many Indian arts and crafts are now being mass produced - by non-Indians and usually in a foreign country. Some of the down grading of Indian arts and crafts is blamed on the white society, but this may not be accurate, since to produce fine arts and crafts takes time and some of the younger Indians feel it is not worth the time. On the other hand, there are "Indian schools Iocated in Santa Fe, Albuquerque, Fort Wingate, Shiprock, and Thob (Cjty), (that) have Navajo master craftsmen as instructors. They instruct young silversmiths on the methods of the craft, using designs of the best traditional patterns". 32 The arts and crafts done by Indians in the past are changing from "necessity" to imitation - therefore, the stanp on the underside of a pot saying "made in Japan". Fewer than half of the respondents indicated they agreed that Indian-ness involves knowing one's native arts and crafts, although such knowledge was once an essen-

30 Ruth Underhill, Ph.D., Rueblo Crafts, (Lawrence, Mansas: HaskeIl Institute Print Shop), March 1948, p. 135.

33. Ibid., p. 136 .

32 John Adair, The Navajo and Pueblo Silversmiths, (Norman: University of Oklahoma Press, 1944), p. 201. 
tial element of tribal economics and religion. The ability to make one's native arts or crafts, could strengthen one's Indianness in much the same way as do extended family ties and knowledge of tribal language. And it is all of these which contribute to the urique cultural background of the. Indian.

The inique cultural background of the Indian people was discussed at a conference of the American Anthropological Association, held at the University of Chicago on February 20, 1954 :

The members all agreed that despite external. pressures, and internal change, most of the present identiriable Indian groups residing on reservations (areas long known to them as homelands) will continue indefinitely as distinct social units, preserving their basic ralues, personality, and Indian way of life, while making continual adjustments, often superficial in nature, to the economic and political demands of the larger society. 33

UIP respondents, however, indicated indifference or neutrality, regarding the uniqueness of an Indian's cultural background. This could be an indication that they are the children of intertribal or Indian-non-Indian marriages. Or they could have been raised in an urban environment where their primary contact is with Indian people, who have mixed heritages. 34 Furthermore, the respondents in this group indicated (except for five) that they had all at attended public schools, and of these, only nine, had ever lived on a reservation. The inclination, therefore, is

33 Clyde Klucishohn, "Covert Culture and Administrative Problems," American Anthropologist, XXXXV(April-June 1943), p.389.

34 Wurray I. Wax, Indian Americans Unity and Diversity, (Englewood Cliffs, New Jerser: Prentice-Hall, Inc., 1971), p. 192 . 
to assume that these respondents have become more assimilated or urbanized and therefore "less Indian" because they are less aware of an integrated Indian cultural past.

Retaining one's Indian identity poses a problem for Indians Iiving and working in an urban environment. In our context, we wished to know if it was also a problem for Indian professionals who leave their home lands, advance their education, and develop expertise in a dominant society profession. Can he the Indian professional, keep his Indian-ness in the back of his mind or somewhere in his consciousness and to experience when needed? When looking at Indian professionals, one must keep in mind that in the United States there are few recognized Indians who are professionals. In the medical profession, for example, there are 38 Indian physicians, ore Indian dentist and three hospital administrators. 35 of these professionals, few ever return to their own reservations. In one instance, at a Convocation of American Indian Scholars, a Pueblo dentist was asked: "Do you think the acceptance by Indians of other Indians from other reservations would be greater than of non-Indians?" 36 His answer was "yes, defiritaly." He then related his. own experience, when he first began his practice:

Even before I arrived, the people would say, we have an Indian dentist coming. And I could have been the worst dentist in the world, but the fact that I was Indian,

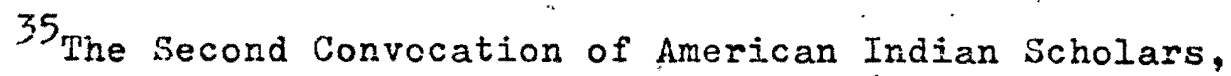
Indian Voices: The Native American Today, (San Francisco: Indian Historian Fress, 1974), p. 151-2.

36 Ibid., p. 158. 
the patients were all waiting, whereas it's been the experience of non-Indian dentists on an Indian Reserration, to spend upwards of eight months to a year, just getting acquainted with people before they were asked to provide any kind of services. 37

It appears there is a tendency for Indian professionals to be accepted more readily in Indian communities other than their own. Perhaps by first gaining acceptance and recognition in another community, others will be encouraged to become more receptive to Indian professionals who might want to return to their own people? 38

It should be emphasized that not all tribal communities encourage their younger Indians to return. If one should decide to try to return he may "find that the power structure on the reservation isn't behind him" or the tribal members may "resent" his acquired training and skill. 39 The rationale appears to be "all right, now you're a city boy and you don't understand things about reservations anymore. ${ }^{40}$ These same people, ironically enough, may have encouraged the same youth to go outside the reservation in order to advance his education and help his people. Praditional Indian communities consistently reflect these dilemmas and contradictions. On the one hand, it is sensible to learn to live in the white man's world; on the other it is too threatening to an élready harassed traditional way of life. The

37 The Second Convocation of American Indian Scholars, Indian Voices: The Native Anerican Today, (San Francisco:: Indian Histo Historian Press, 1974i, p. 157.

$$
\begin{aligned}
& 38 \text { Ibid., p. } 106 . \\
& 38 \text { Ibid. s: p. } 42 . \\
& 40 \text { Ibid., p. } 42 .
\end{aligned}
$$


sanctions the young receive are thus contradictory and ambivalent at best and always present wherever there are Indiars.

Indian Experience of the Urban Indian

Questions 6,7 and 8 on the questionnaire deal with the "Indian experience of the Urban Indian." These three questions reflect just a few of the activities any Indian in an urban community has available to him. Other activities could include Indian dances, meetings with other Indian groups in the city, and Indian clubs for both men and women.

The population means for all three questions, indicate indifference or neutrality. Question 6, dealing with Indian participation in rodeos, and question 7 , referring to Indian participation in city pow-wows, show the individual group means all reflecting neutrality or indifference. In question 8 , "to be Indian is to support the American Indian Movement (AIM) and its leaders", the population means indicates neutrality or indifference. UIP means (3.82) show neutrality or indifference with a slight tendency towards agreement. The BIA means (1.68) indicates disagreement with the question. NCORI and IHS both reflect the population means of neutrality or indifference.

Rodeos may have begun with the Indians. The rodeo itself was born through observation of Indians "playing" on their horses. What looked like "playing" was the Indian developing his horsemanship skills. It was the white man, however, who discovered how to make money out of the rodeo. 4 I

4I WIIiam Eastlake, "Today is Joy to Their World," Sports Illustrated, Septembex 23, I974, p. 33. 
Jsually associated with rodeos are pow-wows. The word "pow-wow" might have had an Algonkian origin, developed in the nineteeth century, to describe a form of secular dancing taken from ceremonials done in the Plains region of the United States. 42

Fow-wows in the city have a different meaning and feeling, than do pow-wows held on tribal lands. The city pow-wow could be viewed as an intertribal event, containing:

large commercial enterprises involving white entrepreneurs, regular dances at intertribal social centers in large cjties, and the dancing that constitutes the social side of otherwise serious intertribal meetings. The greater number of different tribes represented the greater the success of the affair. 43

It should be pointed out that not all Indians who might be Iiving: in the city attend what Joan Ablon in an articie on Urban Indiars, regards as "artificial pow-wows". By this she means pow-wows which lack the "benefit of home community, relatives, friends, and the serving of traditional foods. 144

Although many do care to join in Pan-Indian dancing, others find no necessity to recharge or reify their Indian-ness nor do they think of Pan-Indjan activities as relevant to their personal Indian identity or tribal interests. 45

The other kind of pow-wow is the tribal pow-wow. In some parts of the United States this event is principally thought of as a

${ }^{42}$ Eleanor Burke Leacock and Nancy Destreich Lurie, eds. Native American Indian in Histopical Perspective, (New York. Random House, 1971), p. 449.

43 Ibid., p. 450

${ }^{44}$ Joan Ablon, "Relocated American Indians in the San Francisco Bay Area," Human Organization, XXIII, (1965), p. 720. 45ibid. (my italics) 
ceremonial:

The tribal pow-wows "whether of not it seeks to attract tourists, is ... primarily a community effort in which local customs and language are evident. These pow-wows build community solidarity". 46

The tribal pow-wow is what some Indian people regard as the only traditional or authentic Indian pow-wow. It is for this reason that these same Indians choose not to:attend city pow-wows. Further, Indian center pow-wows may at times be sponsored by the American Indian Movement (AIM). AIM was founded in July, 1968, by George Nitchell, who drew up the charter, and Dennis Banks, in Minneapolis. 4 The movement could. be said to be an urban phenomenon. To an Indian who has either lived or worked in rural areas or on tribal lands, several hundred miles from a metropolitan area, AIM's frame of reference seems very remote. For he who works or lives on tribal lands; is among tribal members, and is itimately a part of a tribe's customs and language, there is no need to focus the harsh iight of publicity on oneself in order to call attention to one's Indian-ness. An Indian who knows he is Indian, need tell no one. He just simply is.

Contact With the Non-Indian World

Questions 9 and 12 deal with Indian groups and their interw

46 Eleanor Burice Iurie and Nancy Oestreich Lurie, eds., Native American Indian in Historical Ferspective, (New York: Razdom House, 1971), p. 450-51.

47 liobert Eurnette and John Koster, The Road to Wounded Knee, (New York: Bantam Books, Inc., 1974), p. 196. 
aotion with other groups. Questions 10 and 16 deal with the Indian experience in the education system. Questions 11 and 13 refer to government employed Indians and Indian interaction with white society.

The population means on questions 9,13 and 16 indicate neutrality or indifference. On these same questions the population means is also reflected on the four individual group means. The population means on questions 10,11 and 13 indicate agreement with the statement. In question 10, dealing with the lack of Indians having a college education, of the four groups, only UIP (3.26) indicated neutrality or indifference. The IIth question, dealing with the lack of Indian people in administrative and/or supervisory government positions, the BIA group (5.0) indicated strong agreement with the statement. In question 12 , "most Indians like to be with others who share their ideas and beiiefs in group discussions and meetings", the NCORI group means (3.72) indicates neutrality or indifference. Interestingly, the questionnaire was distributed during a conference held by the National Council of off Reservation Indians. The purpose of the conference was to gather and share ideas about the direction and membership duties of NCORI, yet the response from these people on question 12 appears to indicate a contradiction in interpretation on the part of the members.

It could be said that some young Indians. are very forceful, especially if they have a cause to believe in. An example, are the philosophies of the American Indian Movement. On the other hand, Inciian people like to gather with other Indians and share ideas on 
common experiences, especially if they are in a new environment and by chance meet other Indians in a similar situation.

"Indian migrants to the city exhibit the same patterns as European migrants of a half-century ago. Given the opportunity, they cluster together residentially and elaborate distinctive institutions which are neither traditional nor urban middle class, but which enable them as a community to fabricate a meaningful existence in this new environment." 48

The spontaneous gathering that occurs among newly arrived Indian to the city, serves the purpose of reinforcing their Indian identity and enables them to cope with "city life".

Indian identity can be suppressed as well as reinforced. This suppression is seen at times in government operated Indian boarding schools. During the time between 1889 and 1892, there were twelve newly opened boarding schools, operating from old abandoned army forts.

"Chilaren were removed, sometimes forcibly long distances from their homes; the use of Indian languages by children was forbidden under threats of corporal punishment; stum dents were boarded out to white families during vacation times, and native religions were suppressed."49

The rationale behind this removal of children from their native land and family wes to better prepare the child to become an American and less Indian. 50 This happened in the late $1800 \mathrm{~s}$, but some educational institutions in the past few years have not advanced much further in their conceptions of education for the

48 Wax, p. 163

${ }^{49}$ Estelie Fuchs and Robert J. Havighurst, To Live on This Earth: American Indian Education, (Garden City, New York: Anchor Fress/Doubleday, 1973), p. 225.

50 Ibid 
American Indian. The purpose is still assimilation with the great American "melting pot" and not education in the truest sense of the word. What results is that the Indian student leaves school because of the frustration of being pushed aside by teachers, books, and other students. In order to survive in the educational system the Indian must have competed, especially for grades. Because a student's worth is determined by grades, for the student who comes from a non-English-speaking background, the chances of survival are very minute. 51 More often now, however, school systems reflect positive change. They are beginning to include bilingual studies, Indian culture and history, and vocational training. Also, Indians are understanding the tremendous importance to themselves and to.others of qualitiy education and equality of educational opportunity. 52 Even with this new awareness in education, among past-secondary school students, the ratio between those going to college and those going to technical-vocational schools is about 3 to 4.53 . In addition, the estimate, in I9\%0, of three thousand Indian high school graduates entering college, only about one-fourth of whom will Eraduate with a baccalaurate. 54 Based on the above, the NCORI group means (4.90), showing a slight tendency toward strong agreement with the question

51 Joe E. Sando, Needed Change to Serve Indians, an unpubIished paper.

52 Fobert I. Bennett, "The New Indians and the OId Indians: Cultural Factors in the Education of American Indians," Shirley Hiil Witt and Stan Steiner, eds., The Nay, (New York: Random House, Inc. . 1972), p. I29.

53 Fuchs and Havighurst, p. 261.

54 EDid., p. 260. 
dealing with Indians not having a college education, also had the nost members with past-secondary education level. Hopefully, their experience will provide others with the knowledge of the difficulties involved in pursuing a college education and of how to overcome these.

The question dealing with having more Indian people in government administrative and supervisory positions, received strong agreement from the BIA respondents $(5.0)$. The reason for this may be that since the Bureau of Indian Affairs is set up to help Indians, therefore only an Indian can understand the Indian and his problems. On the other hand, as Ms. Ablon has said, "Indians generally do not want to compete with others." 55 In order to hold either of the positions stated above, one must compete. This theme is repeated as follows:

"The (employees have) done all right in their present jobs and made advancements, but they were afraid that if they took that next step and became supervisor, they might not be big enough for the job." 56

If this is so, then how did some Indians become administrators or supervisors?. One answer to this is that the Indian who obtains a fairly high paying job, that provides a reasonable standard of Iiving, improves his chances for staying and for adapting to the new culture and its values. 57 . By thus adapting to the white or

55 ÁbIon, p. 713.

56 Donald Greve, "The American Indian," Vital Speeches, XXXVI (February 1, 1970), 278.

57 Robert s. Weppner, "Urban Economic Opportunities: the example of Denver," Jack 0 . Waddell and $O$. Michael Watson, The American Indian in Urban Society, (Boston: Little, Brown and Company, 1971j, p. 240. 
dominant standard of living and values, he also learns to compete - for what he wants. It couIa be that some of the BIA respondents are reaching, if some have not already, this economic integration point. With this in mird, obyiously, Indians will continue to obtain higher paid positions.

In achieving economic integration, the Indian will most Iikely associate with more and more non-Indians. Thus, the BIA response indicating neutrality or indifference to the question of having nore non-Indian friends and associates, appears to contradict their strong agreement with the position that more Indians ought to be in supervisory and administrative positions. Having contact with non-Indians does not always occur in working positions, although such contact occurs more often in the city. "Many Indians say that they have more contact with non-Indians than with other Indians. "58

Some Indian people have non-Indian friends but may be embarrassed to have it known even on a questionnaire, assuring them of ancnymity. They thereby keep what they are probably experiencing as a lack of Indian-ness, to themselves. They try to hide the fact that they are more comfortable with, or have more white, than Indian friends.

Educational Experiences, Attitudes and Perceptions

The questions in this section were designed to elict

58 Merwyn S. Gakarino, "Iife in the City: Chiicago," Jack 0. Waddell and 0 . Kichael Watson, the American Indian in Urban Society, (Boston: Iittle, Brown and Company, 1970), p. 175. 
responses concerning educational experiences, attitudes toward education, and present and past perceptions of educational opportunities. Questions $18,19,20,23$, and 24 are directly related to school experience or desired school experience. Questions 21 and 25 are related to the respondents view of education in the past and to educational opportunity in the present. Question 22 is related to the respondents attitudes toward the inclusion of curriculum on Indian History and Culture in all schools.

Questions 18 and 23 deal with the school situation in regard to general discrimination and possible difficulties (due to prejudice) of an Indian child's adaptation to schools in Portland or Phoenix. On both questions the population means and ali group means fall within the range of indifference or neutrality. The literature seems to disagree with this position. Although other studies have elicted similar responses, responses were received that verbally denied discrimination where discrimination did exist. A study done" by the Northrest Regional Laboratory on the post high school education of Indian students asked if they had experienced prejudice in the course of their education. Oniy a small number of these high school graduates acknowledged that they had ever been victims of prejudice. The researchers felt that it was possible that the students who went to school where Indians were a majority (as is often the case on tribal lands) were not exposed to discrimination, They raised othar poseibilities however, which may be pertinent to the present study: 
Equaliy possible is that some students would not admit experiencing prejudice. They may have felt such an admission would support the unfourded premises that they as Indians, were inferior to other people. Having heard repeatedly the sterotyped prejudices which are mouthed about Indians, some actualiy appear to believe these canards, if not about themselves, about their fellow Indians.

Still others, perhaps, were reluctant to admit experiencing prejuaice because it might be contrived as seeking to excuse what could be regarded as failure in their lives. Almost all the young people who denied experiencing prejudice readily volunteered accounts of prejudice experienced by their Indian friends and even members of their families. 59

Burnette states that Indian students in urban schools face a "double racial barrier." He feels that white students group the Indian students with blacks and the blacks group them with whites. The end result is that the Indian student becomes $a$ pivotal point for tacial conflict. 60 Similarly, one of us had had personal contact with an elementary school student who felt he was placed in this position in the Portland Public Schools. The child requested and was granted a transfer to another school with a very small number of black students where he no longer might be the racial scapegoat for whites and blacks.

Discrimination in the public schools is more complex than just colnting over behaviors of white students, teachers and administrators against Indian students. The curriculum used and the controlling systems of the school must also be examined. The curriculum used by public school systems either ignores

59 Giohonse D. Selinger, The American Indian Graduate: After High School What? (Portland: Horthwest Regional Laboratory, 1968), p. $73-74$

60. Robert Burnette and John Koster, The Road to Wounded Knee, (New York: Bantam Books, 1974) p. 64. 
the contributions of the American Indian in history or sterotypes Indians. A study done by the University of Idaho found Indians "continually depicted (in textbooks) as inarticulate, backward, unable to adjust to modern Euro-American culture, sly, vicious, barbaric, superstitious and distined to extinction." 61

In reference to history and social studies classes, the president of the American Indian Historical Society testified to the Subcomittee on Indian Education that:

There is not one Indian child who has not come home in shame and tears after one of those sessions in which he is taught that his people were dirty, animal-like, something less than a burian being. 62

The curriculum and textbooks of the public schools are in the realm of school administrators and school boards in each district. The school boards, as representatives of the communty, have the final approval of curriculum and textbook adoption. The 1969 Report on Indian Education found that Indian members or school boards which have jurisdiction in districts containing Indians is rare. In Brockton, Montana, for example, in 1970, the school board was composed of two white men and one Indian; the school population was 98 percent Indian. In districts where the majority of studenis are white it is very rarely ishat the school. board ras ar Indian nember. The report goes on to state that the

62 Committee on Labor and Pubic Welfare, Indian Education: A National Tragedy - A National Challenge. 1969 Report of the Comitiee on Labor and Irublic Welfare, United itates Senate, Made by the Srecial Subcomittee on Indian Eduation. Washingtor D. C.: the Comittee, 1969.

62 Ibid. 
White power structure of the communities where Indians also reside, thwarts Indian attempts to gain representation on school boards. 63 The facts seem to indicate that there has been and continues to be discrimination against Indian students overtly in curriculum and inherent in the structure of the public school districts. It is also true that Indians themselves have been the last to protest institutionalized racism of any kind." The Indian response has been to tolerate, to withdraw or, as recently in the case of education, to create alternative schools of their own.

Two of these alternative schools developed by Indians are the Rough Rock Demonstration School at Chinle, Arizona, on the Navajo Reservation and the Rocky Boy School on Rocky Boy Reservation in Nontana. The Navajo tribe organized a non-profit organization in 1968 to receive funds from the Bureau of Indian Affairs and the Office of Econonic Opportunity for a school. The corporation then turned over the school to a board of education, consisting of fiva Navajos (none of whom, by the way, had a high school education.) The school has been committed to developing a bicultural, bilingual programi for 250 students from Head start through grade ten and has been successful. 64

The Rocky Boy School was formally attached to another public

${ }^{63}$ Convittee on Labor and Public Welfare, Indian Education: A National Tragedy - A National Challenge. 1969 Report of the Conmittee on Labor and Fublic Welfare, United States Senate, Made by the Special Subccmmittee on Indian Education. Washington, D. C.: the Subcomittee, 1969.

${ }^{64}$ Fste1le Fuchs and Robert J. Havighurst, To Live on This Earth: American Indian Education, (New York: Anchor Press, 1973) p. $25 \%$. 
school district thirty miles away. Several years of tribal effort resulted in the formation of an independent public school district. in the late sixties which could obtain separate funding.

The Rocky Boy Reservation then became an independent public school district with separate funding, and controlled by a five-member, all-Indian Board of Education. This board hired an Indian from the reservation as superintendent.65

The school district is developing programs in bicultural education and there is a bilingual program for 5 years olds.

The Rough Rock School and the Rocky Boy School have the advantage of being able to influence the education of Indian children because of the absence of white families in these areas. In areas with mixed white and Indian populations the alternative school is not always feasible. However, in school districts where the schools receive federal funding because of the presence of sizeable numbers of Indiar students, the schools are required to form and utilize advisory committees of Indian people. These advisory committies, or boards, ideally should have authority over the expediture of Johnson O'Malley funds which are specifically designated for Indian students. Indian Adivsory groups and Johnson O'Malley funds have sometimes given Indian people in mixed communities more influence in: the school's decisions about curriculum and programs.

To question 19, Most Indians can learn more and be more comportabie when they attend school with other Indian students," the totis population, except for the IHS group, indicates

65 Estelie Fuchs and Robert J. Havighurst, To Iive on This Earth: American Indian Education, (New York: Anchor Press, 1973) p. 256 . 
nertrality or indifference.

The feeling that Indian people are equal in ability and can compete favorably with non-Indian children in schools could have influenced the responses. The respondents may have felt that by agreeing they would be implying that Indian people need special education because of intellectual or social inferiority. AdditionlIy, since many of the respondents in the UIP, BIA, and NCORI groups are residents of urban areas where non-Indians are a majority, they may have never felt uncomfortable with non-Indians or they may have forgotten any uncomfortable feelings they may have had in the past.

The IHS group's agreement with this statement, on the other hand, supports the findings of the National Study of American Indian Education directed by Estelle Fuchs and Robert Havighurst. In this instance, forty school districts and schools were surveyed. The youth and parents in these districts evaluated the schools in their area. The schools about which the students and parents had the most positive feelings were schools where Indian students were a majority. Fuchs and Havighurst felt that a possible reason for this positive evaluation may have been the racial make-up of these schools:

Indian students, for the most part, prefer all-Indian schools. In such schools Indian students may feel more comfortable and less anxious about discrimination, being accepted by peers, bein: as well dressed as other students, etc. Moreover, the outstanding students and athletes have to be Indian in an all Indian school. 66

66 Estelle Fuchs and Robert J. Havighurst, To Iive on This Earth: Americar Indian jucation, (New York: Anchor Press, 1973) p. 158. 
Although the popliation mean indicates agreement with question 20, "All Indian children should have the chance to attend a public integrated school." The small groups are divided in their means. The BIA and IHS strongly agree with this statement. This is especially interesting in view of the fact that on the preceeding question, the IHS group indicated agreement to the statement "Most Indians can learn more and be more comfortable when they attend school with other Indian students."

There is a possibility that these groups believe public integrated schools are superior to BIA schools and mission schools which are normaly the Indian alternative to public schools. This may not be an unrealistic belief. Many authors have made statements about the inferiority of Indian education in BIA boarding schools. The assumption that the problems of Indian students high dropout rates; absenteeism; overageness; and underachievement - relate to negative school environments in BIA schools may have been made by the respondents. The public school may thus seem a more desirable alternative.

Much has been written critisizing Indian education in the past. In 1926, the Brookings Institute investigated Indian affairs for the federal government and in 1928 published the Meriam Report. The educational section of this revolutionary report recomended many changes in Bureau of Indian Affairs boarding schools. The most pervasive change argued for "individualistic, non-autioritarian, decentralized education in which the focus would be on the whole individual and his relationship to his family and 
community." 67 Changes were instituted soon after the publication of the Meriam Report. Some boarding schools were converted to day schools; improvements were made in the academic curriculum; the qualifications necessary for teaching were raised, and student care improved. 68 However, the progress made in the thirties and forties, following the Meriam Report, was halted by World War II, "as a lack of funds joined with a congressional attitude of 'deIndianizing the Indian." 69 Thus, the special Subcommittee on Indian Education, 4 years late:, found many of the same problems that were present in 1926. In summary, this later report stated:

We have concluded that our national policies for educating Ainerican Indians are a failure of major proportions. They have not offered Indian children - either in years past or today - an educational opportunity anywhere near equal to that offered the great bulk of American children. 70

The respondents, therefore, are viewing reality objectively when they agree with the statement, "Indians in the past received a "second rate" education." (Question 21.)

Concerning the opportunities for education today, the study population indicated indifference to the statement, "Today's Indian has the same educational opportunities as a non-Indian." The ore exception was the BIA group which agrees with the state-

67 EsteIle Fuchs and Robert J. Havighurst, To Live on This Eartis: American Indian Education, (New Hork: Anchor Press, 1973) 68 Ibid., p. 227.

${ }^{69}$ Committee on Labor and Public Velfare, Indian Education: A National Trafedy - A National Challenge. 1969 Report of the Committee on Labor and Public Nelfare, United States Senate, Made by the Special Subcommittee on Indian Education. Washington, D. C.: the Subcommittee, 1969.

$$
70_{\text {Ibjd. p. }} \text {. xi. }
$$


ment.

Fossibly the BIA group views educational opportunities more positively because of their personal successes and their knowledge of the assistance available from the BIA. This, of course, assumes that BIA employees are more aware of BIA programs than individuals not airectiy associated with the BIA. The BIA group was the only group in which all members had graduated from high school. How ever, NCORI, with the most members possessing higher education experience, had the lowest mean ion this question. The NCORI members may feel that it was difficult for them as Indians to obtain. their education and that this is still true.

The general inferiority of education of Indian children seems to be an accepted fact. Yet, the population of this study does not place the responsibility for the high dropout rate on either the school situation or on the lack of ability of the Indian student. The population mean was neutral when they responded to the statement, "The high Indian dropout rate is caused by the school situation rather than the lack of ability on the part of the Indian student." Two groups, however, UIP and NCORI, agree that the school situation is the cause of the high dropout rate. Brewton Berry in his survey of the literature on education of American Indians discusses the problem of low achievement and overageness which seem to contribute to the high dropout rate of Indian students. His data shows there is a general low achievement rate in Indian students after the primary grades. Low achievement is defined as receiving scores below state and national 
averages on achievement tests. The Indian student also tends to be overage for his grade level. 71 .

Various reasons for the decline of academic performance es Indian students move through school (the "cross-over" phenomenon) have been postulated:

1. The cross-over phenomenon is charactexistic of adolescents and is peculiar to Indians.

2. It is a result of the acculturation process. The younger children learn the obvious elements of the culture (white culture) quickly. The broad cultural experiences which are available to the general. population are not available to the older Indian students. 72

3. Alienation is the central concept for explaiiling the problem. The conflict between white and Indian cultures comes to a focus at adolescence and causes severe personality disturbances which block achievement. 73

If one agrees rith this explanation, by the time the Indian student reaches high school he is apt to be older than his classroom peers and has a lower level of achievement. This state, whatever the reasons, is obviously conducive to dropping out. The question of who is responsible for this phenomenon: the situation, or the student is complex.

71. Brewton Berry, The Education of American Indians: A Survey of the Iiterature, (U. S. Department of Heaith, Education and velfare, 1968 ), p. 30 .

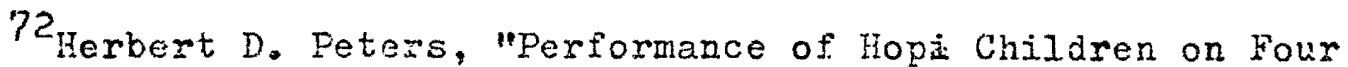
Intelligence Tests", Journal of American Indian Education, II; $2:$ p. $27-31$.

73 John Bryde, "The Sioux Indian Student: A Study of Scholastic Failure and Eersonality Conflict." Ph. D. University of Denver, 1965. (As ajted in: Brewton Berry, The Education of American Indians: A Burvey of the Literature (U.S. Department of Health, Education and Welfare, 1968) p. 32. 
Willard Bass states that the causes of the poor education of Indian students are:

... irrelevant curricula, inappropriate learning materials, inadequate teachers, poor home environment, poverty, isolation, lack of student motivation, language handicaps, cultural conflicts, and an absense of Indian involvement and control. 74

These causes are a combination of school-related and familyrelated problems. Improvements in the education of Indian children will only be possible when the total situation is improved. Looking specifically at the school situation, Bass recommends these remedies for some of the educational problems of Indian students; "bicultural education; special training for teachers; more Indian teachers; development and use of Indian cultural learning materials and more involvement and control by Indians." 75

Hopefully, schools like the Rough Rock Demonstration School and the Rocky Boy School are beginning a trend which will provide some of these elements to Indian education. The federal funds available to gublic schools for the education of Indian students should even facilitate the incorporation of these solutions by public schools.

The respondents indicated agreement with question 22 , indicating, perhaps, that Indtans can learn to be proud of their Indianness if the curriculum teaches them to understand and respect theix

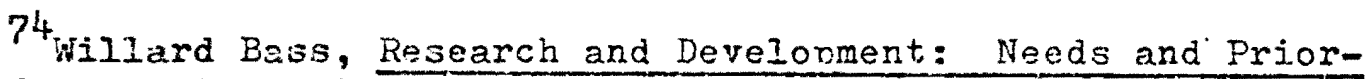
ities for the Education of American Indians. Pinal Report. Clbuquerque: U.E. Deparcient of Health, Education and Welfare, 1971), n. 7 .

$$
75 \text { Itid... p. } 9 .
$$


past. The reassessment of history from an Indian point of view has been manifest in recent years by a surge of movies and books which address the questions of Indian-ness from the Indian point of view. Just a few which have had great impact are Dee Brown's, Bury My Heart at Wounded Knee; Vine Deloria, Jr.'s, Custer Died for Your Sins;" "Iittle Big Man" and "A. Man Called Horse." The awareness that Indians have a culture and place in American history, other than as an obstacle to the colonization of the United States by the white European, is a relatively new concept for the majority of us all. The view point of today's Indians on the Indian's role in history is a fascinating choice for further study. Bince it appears very likely that many Indians have accepted the negative stereotypes of themselves which have to date been perpetuated by the media and by the schools, the inclusion of Indian history and culture in the curriculum will, ideally, give both Indian and non-Indian a realistic view of the Indian's role in and contribution to the history cf mankind. 
A. SHTECTED BIBLIOSRAPHY

\section{Books}

Adair, John. The Navajo and Pueblo Silversmiths. Norman: . University of Oklahoma Press, 344

Burnette, Robert and John Koster. The Road to Wounded Knee.

New York: Bantam Books, 1974.

Debo, Angie. A History of the Indians of the United States. iorman: University of OkIahoma Press, 1970.

Fuchs, Estelle and Robert J. Havighurst. To Live on This Earth: American Indian Education. Garden City, New York: Anchor Fress, 1973.

Leacock, Eleanor Burke and Nancy Oestrich Lurie, eds. Native American Indian in Historical Perspective. New York: Random House, 1971.

The Second Convocation of American Indian Scholars. Indian Voices: The Native American Today. San Francisco: Indian Historian Press, 1974 .

Selinger, Alphonse D. The American Indian Graduate: After High School, What? Portland: Northwest Regional Laboratory, 1958,

Stoutenburgh, John I., Jr. Dictionary of the American Indian. New Tork: Philosophical Library, 1960.

Underhill, Ruth, Ph.D. Pueblo Crafts. Lawrence, Kansas: Haskell Institute Print shop, 1948.

Waddell, sack 0 . and 0 . Michael Watson. The American Indian in Urban Society. Boston: Iittle, Brown and Company, 197I.

Walker sit Center Indien Art Association, The Minneapolis Institute of Arts. American Indian Art: Form and Tradition. New York: E. P. Iutton and Company, 1972.

Washburn, Wilcomb E. Red Man's Land - White Man's Law. New York: Charles Scribner's Sons, 1971. 
Waz, Murray I. Indian Americans Unity and Diversity. Englewood Cliffs, New Jersy: Prentice Hall, Inc., 1971.

Winick, Charies. Dictionary, of Anthropology. New York: Philosophical Iibrary, 1956.

Witt, Shirley Hill, and Stan Steiner, eds. The Way. New York: Random House, 1972.

\section{Articles}

Ablon, Joan. "Relocated American. Indians in the San Francjsco Bay Area," Human Organization, XXXII Winter (1964), p. 712-727.

Eastlake, William. "Today is Joy to Their World," Sports Illustrated, September 23, 1974, $\mathrm{p} ; 33-37$.

Fontana, Bernard I. "Savage Anthropologists and Unvanishing: Indians of the American Southwest," The Indian lijstorian, VI, winter (1973), p. 5-8.

Greye; Donald. "The American Indian," Vital Speeches, XXXVI (February 15, 1970), p. 276-279.

Kluckhohn, Clyde. "Covert Culture and Administrative Problens," American Anthropolocist, XXXXV. (April-June, 1943), p. 213229.

Lesser, Alexander. "Education and Ehe Futare of Tribalism in the United States: The Case of the American Indian," Social Service Review, XXXV (June 1961), p. 135-143.

Medicine, Bea. "The Anthropologist as the Indian's Image Makermaker," The Indian Historian, IV, Fall, (1971).

Nelson, Mary. "Problems. Indian Students Face," The Indian Historian, V, jummer (1972), p. 22-23.

Wilson, Haggie. "From Phoenix Convention Center," Arizona Highways, II (May, 1975), p. 15.

\section{Govemment Publications}

Bass, Millard. Research and Development Needs and Priorities for the Education of American Indians. Albuquerque: U. S. Department of Health, Education and velfare, 1968. 
Special Senate Subcommittee on Indian Education. Indian Education:

A National Tragedy - A National Challenge: Washington, D. C., Superentendent of Documents, 1969. (1969 Report of the Committee on Labor and Public Welfare, United states Senate.) 
;

$=$

i

r

:

i

r

r
$:$

i

'.

1

;

,

APPENDIX A

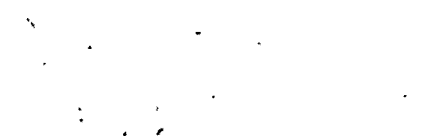

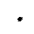

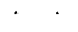

.
: 


\section{QUESTIONIAIRE}

Sex: Female

Male

Age :

Marital Status: Single

Married

If married, number in family

Other Number of children in school

What is your tribe?

Are you enrolled on the tribal census? Yes

No

What state is your tribal land located in?

Terminated or not?

Do you have contact with friends or relatives, who are also from from the same tribe or area, as yourself?

Ies No

Have you ever lived on a reservation? Yes No If so how many years?

$1-5$ years 20-25 years 5-15 years $25+$ Jears 15-20 years

Do you speak your tribal language, more than just a few basic words? TeS No

Did you receive MOST of your education (elementary/secondary) at: a B. I. A. or government school?

or a Public school?

Was this school on tribal. lands? Yes No

What was the highest grade completed?

Technical or business college 
Junior or Comnunity College

Four yaar college or university

Post Graduate

Respond to the following statements. Chech the box that best represents your feelings about each statement. Checking the first box is to agree, and the last to disagree with the statement. 5y chicking the middle box, you neither agree or disagree.

To be an. Indian is to be able to speak his tribal language and "English."

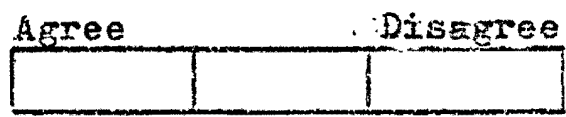

To be an Indian is to know his native customs and traditions.

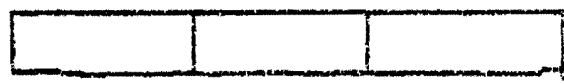

An Indian is an individual with an unique cultural baciground.

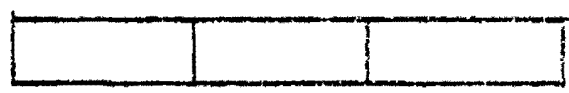

To be an Indian is having parents and relatives, who live on a reservation.

To be an Indian is to know one's native crafts, for example, beading and weaving.

Most Indians like to participate in rodeos.

To be an Indian is to participate in Pow-wows held in the city.
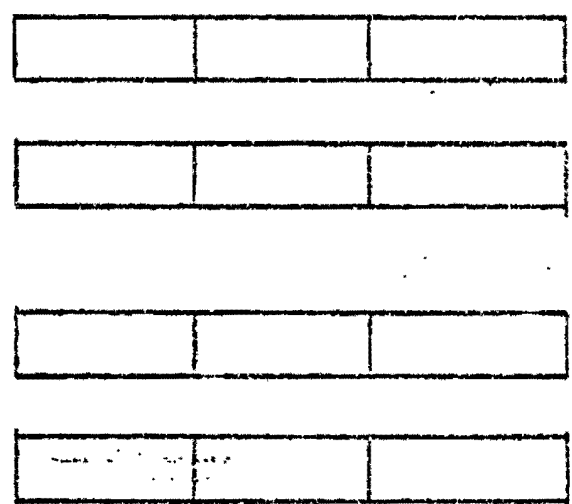

To be an Indian is to support the American Indian lovement (AIM) and its leaders.

Dome Indians try to force others (both Indians and non-Indians) to see their point of view.

Kost Inaians do not have a college education or a college degree.

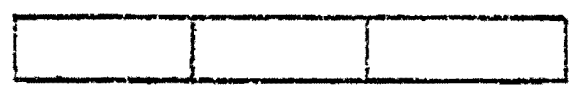

Most Indians feel there should be nore Indians worting in goverrment (BIA/IHS) supervisory and/or administrative positions, than in clerical positions.

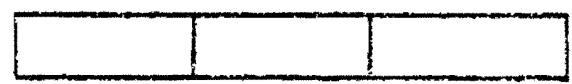

Most Indians Iike to be with people who share their ideas and beijefe in broup discussions and meetings.
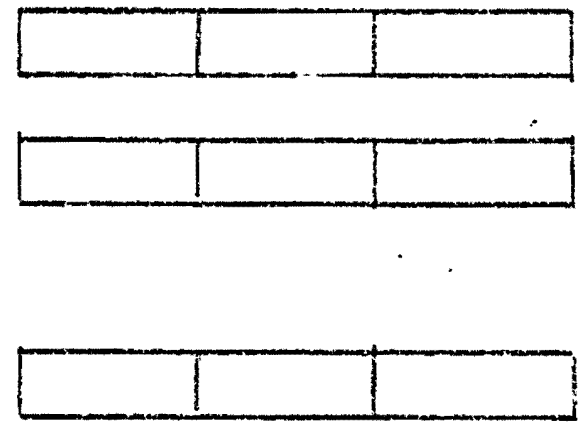
Most Indians have a lot of white friends and associates.

To be an Indian is to become a professional (Social Worker, Administrator, etc.) yet keep all his

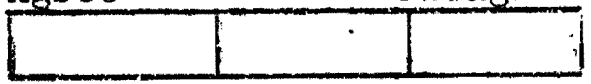

Indian-ness."

To be an Indian is to return to your tribal lands, to help your own people, for example, a law student.

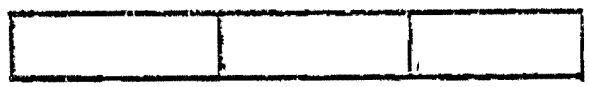

Mosf Indians learn the way of the "white man in a government boarding school.

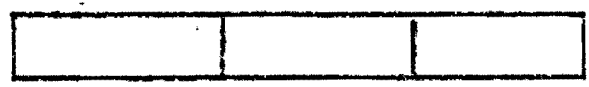

To be an Indian is not "selling out" to the white man's world, and becoming an "Apple Indian".
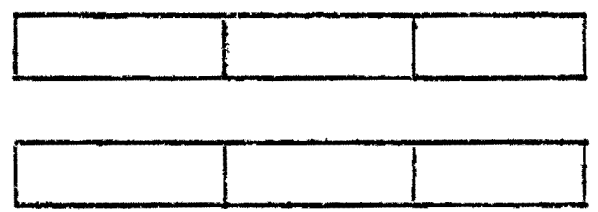

To be an Indian is to suffer discrimination in the public schools.

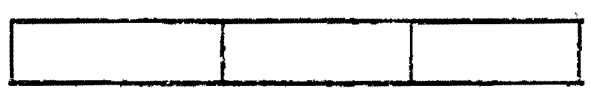

Most Indians can learn more and be more comfortable when they attend school with other Indians.

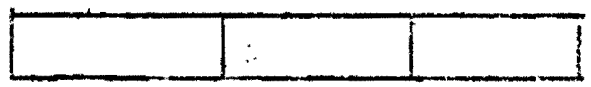

A1I Indian children should have the chance to attend a public, integrated school.

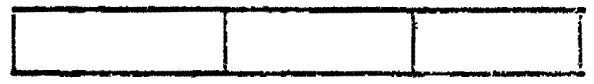

In the past Indians received a "second rate" education.

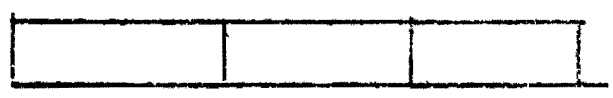

All students, Indian and non-Indian should be requirad to take classes in Indian history and culture.

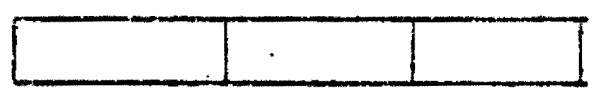

It is difficult for Indian children to adapt to schools in Portland/Phoenix.

The high Indian dropout rate is caused by the school situation rather than the lack of ability on the part of the

Indian student.

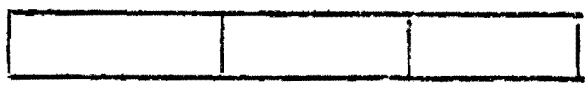

Today's Indian has the same educaticnalopportunities as a non-Indian.
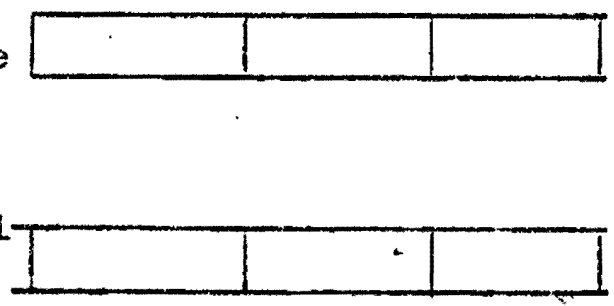
APPENDIX B

$r$

$i$

;

i

r

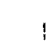

।

i 


\section{DEMOGRAPHIC DATA}

Sex

Female $55 \quad$ Male 21

Age

$\begin{array}{llll}\text { Average } & 35.57 \text { years } & \text { Under } 35 \text { years } & 33 \\ \text { Range } & 16 \text { to } 65 \text { years } & \text { Over } 35 & 43\end{array}$

Marital Status
Single 22
Married 44
Other 10

Tribes Reoresented
Alseacheto
Apache
Assiniboine
Chippewa
Colville
Creek
Eyadmoiel
Flatheac
Gros Ventre
Havasupai
Kiowa Creed
Lower Umpque
Modoc

\author{
Navajo \\ Nez Perce \\ Painte \\ Quinalt. \\ Shawree \\ Shoshone Bannock \\ Sioux \\ Tewa Hopi \\ Tillamook \\ Tlingit \\ Umatilia \\ Yakima
}

States Represented
Alaska
Arizona
California
Idaho
Minnesota
Montana

\author{
North Dakota \\ Oklahoma \\ Oregon \\ South Dakota \\ Washingtom \\ Wisconsin
}

Contact With Friends or Relatives

Yes 72 No 4


Iived on Reservation

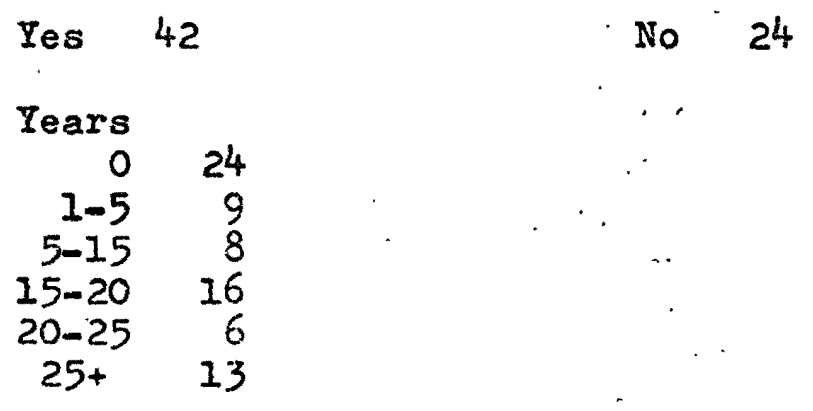

Speaks Tribal Language

Yes $29 \because$ No 47

Education

Received Education At:

Bureau of Indian Affairs School

Public School

No Answer

Location of School:

On Tribal Lands 45

Off Tribal Lands 16

No Answer 15

Highest Grade Completed:

Below Ilth Grade 25

Completed 12th Grade $\cdot 13$

Technical of Business College 15

Junior College

15

Four year College or University 10

Post Graduate 